\title{
RECENT DEVELOPMENTS IN WRONGFUL DISMISSAL LAWS AND SOME POINTERS FOR REFORM
}

\author{
G. ENGLAND*
}

\begin{abstract}
This paper examines recent developments in the law of wrongful dismissal. It demonstrates that the current common law fails to regulate satisfactorily terminations of employment and proposes an alternative statutory scheme. Part $I$ considers the "minimum contents" required of a fair and just system of employment termination. Part II examines the common law response and its inadequacies. Part III suggests proposals for reform, drawing on the ex. periences of statutory "just cause" protections in Nova Scotia and England and in Canadian grievance arbitration. Also, the proposed amendments to the Canada Labour Code in bill C-8,1 which introduces "just cause" protections for workers within Federal jurisdiction are considered.
\end{abstract}

\section{THE PROBLEM: REGULATION OF THE EMPLOYER'S POWER TO TERMINATE EMPLOYMENT}

Disputes over terminations of employment are, like strikes, endemic to the system. There is an inherent conflict between the interest of the employer, which is essentially to promote "efficiency", and that of the worker, which is essentially to guarantee his "security".

For the employer, the corner-stone of the employment contract in our system of economic organization is his "right" to discharge. That "right" is necessary to reinforce the "right" of command, legitimated in capitalist ideology as an attribute of private ownership, to protect production against "disruptive" conduct, and to organize operations so as to extract the maximum profit. Further, labour mobility and an available pool of labour are corollaries of the right to discharge. For the employee, dismissal is the capital punishment of industry. ${ }^{1 a} \mathrm{He}$ and his family face the possibility of a long period of economic hardship the more so in a tight labour market, and grave social and psychological upheavals, particularly if he has to uproot his family to a new area in search of work. It is submitted that, in the interests of the employer, the worker, and the "public interest", certain minimum standards of fairness should be imposed by statute on the employer's right to dismiss.

For the worker, it is trite that his bargaining power is significantly less than that of his employer, save in exceptional circumstances. This is particularly so in the non-unionized sector which currently represents approximately sixty-five percent of the labour force, but even in the organized sector some unions have not been able to win "just cause" protections against discharge in their collective agreements. The twentieth century has been marked by a proliferation of protective legislation designed to secure a minimum "floor of rights" for the worker in respect of many employment interests including vacation pay, holidays, minimum wages, wage protection, garnishment, hours of work, safety standards, notice periods, workmen's compensation, equal pay and maternity leave for women, and protections in the event of lay-offs. These protections are a response to the inequality of bargaining power under the

- Professor, Faculty of Law, University of Calgary.

1. An Act to amend the Canada Labour Code, 3rd sess., 13th Parl. 1977 Bill C-8.

1a. See Royal Commission on Trade Union and Employer's Associations (Donovan) (HMSO, 1968, Cmnd. 3623). c. IX, especially paragraph 526; G. DeN. Clarke, Unfair Dismissal and Reinstatement (1969) 32 M.L.R. 532. 
individual employment contract and it is a logical progression of this trend that fairness safeguards be imposed on the employer's contractual right to dismiss. Moreover, there is a glaring gap in Canadian industrial jurisprudence between the organized employee under a collective agreement containing a "just clause" article and the unorganized worker who has inadequate protections at common law. To say that the unorganized worker should organize for self-protection begs the question whether societal values no longer accept self-help as the only, or most desirable means of guaranteeing fair treatment. Indeed, the problems of organizing certain groups of workers may make certification unattainable for them. Safeguards against the abuse of the dismissal power are equally as important, if not more so, than many of the employment interests currently protected by statute. Further, public opinion no longer accepts the unrestrained actions of "superpowers" on personal interests in other areas of the economy. Unfair dismissal legislation can be seen as parallelling the fairness limitations imposed on the actions of such actors which adversely affect personal interests. It has been argued that the worker's job is a "property right" so that, as with the compulsory acquisition of land, it should not be taken from him without procedural safeguards guaranteeing natural justice and full compensation. ${ }^{2}$ This analogy is legally unsound. The worker cannot unilaterally assign his job to a "buyer", nor can he bequeath it to his successor, as he can with his house. Moreover, this view would presumably entitle the worker himself to decide when and if he ought to be dismissed, which goes beyond any statutory protections currently in force in the western world and beyond the protections in most collective agreements. The analogy is dangerous because it assumes that the worker has a vested stake in the capitalist system, that is, that he "owns" his job thereby legitimating the concept of private ownership which generates conflict at work. It is preferable to recognize the uniqueness of the employment relationship and regulate it according to its real-life characteristics rather than to make unreal analogies with property interests.

For the employer, whereas the right to discharge is beneficial, its imposition in a manner which is perceived to be unfair is not. Unjust dismissals undermine morale among workers and create resentment which may manifest itself in various forms of "unorganized conflict", e.g. high labour turnover, sabotage, indiscipline, absenteeism and reduced productivity. Further, as Sayles has demonstrated ${ }^{4}$ informal work groups with shared values and objectives exist even in non-union plants. These groups may respond to unjust dismissals by imposing some form of "organized" sanction such as an illegal strike or collective restriction on outputs, or they may move toward formal unionization.

For the government, it has a clear responsibility to protect weaker members of society against those who exercise superior power over them. As seen, this underlies existing labour standards legislation. It also underlies the legal protections afforded to tenants, consumers of goods, and minority groups. It is consistent with this humanitarian philosophy

2. See Nova Scotia House of Assembly Debates and Proceedings (2nd sess.) (March 24, 1975) at pp. $1499-1503$. Contrast Jackson, Unfair Dismissal. How and Why the Law Works (Cambridge, 1975).

3. See R. Hyman, Strikes (Fontana, 1972), pp. 53-56. Article 2 of the new U.K. Code of Practice on Disciplinary Practice and Procedures in Employment (H.M.S.O. 1977) recognizes the advantage to both sides: "Disciplinary rules and procedures are necessary for promoting fairness and order in the treatment of individuals and in the conduct of industrial relations. They also assist an organization to operate effectively". (Emphasis added.)

4. L. Sayles, Behaviour of Industrial Work Groups (Wiley, 1958). 
that workers in the non-unionized sector and those who are organized, but whose collective agreements do not contain a "just cause" article, should be protected against abuse of the dismissal power. Only one Canadian province has introduced unfair dismissal legislation, Nova Scotia as late as $1975,{ }^{5}$ whereas most Western European countries such as France, ${ }^{6}$ Germany, ${ }^{7}$ England ${ }^{8}$ and Sweden ${ }^{9}$ have afforded protection for a number of years. Amendments have recently been proposed to the Canada Labour Code in Bill C-8 to introduce protections for workers within the federal jurisdiction. Furthermore, in 1962, the International Labour Organization produced Recommendation 119 which recommended legislative protections against arbitrary dismissals. ${ }^{10}$ In view of these precedents, there is an urgent obligation on governments in Canada to introduce protective legislation. Some would argue that governments also have a repressive interest in introducing legislation; namely, that the prevention and control of conflicts arising from discharge has the effect of depoliticizing the issue so as to perpetuate the capitalist system. In other words, the state "buys off" the revolutionary propensities of the working class by imposing certain minimum standards of fairness while preserving the employer's ultimate right to determine the "when and if" of dismissal. Even if this is a conscious objective, most Marxists would not deny the desirability of accepting the crumbs while continuing to struggle for the cake. The crucial question is not whether protective legislation should be introduced, which clearly it must, but which standards of fairness are appropriate for regulating the dismissal power.

There are no scientifically objective standards of "fairness". What is "fair" to one person or societal group depends on its ideological preferences and these may often conflict. Given this limitation, "fairness" in the context of dismissal is generally expressed in terms of procedural safeguards. ${ }^{11}$ The first of these is that "natural justice" standards apply, that is, the worker is given advance notice of the reason for dismissal, the right to present argument and challenge the case against him, the right of appeal to a higher managerial level than that at which the decision to dismiss was taken, and the right of appeal to an outside impartial umpire with legal representation if desired. It is widely accepted that these are "minimum standards" which any public body whose decision may adversely affect an individual's interest must conform to. Corollaries of "natural justice" include these: that the grounds for dismissal not be radically altered in such a way as to "surprise" the employee once dismissal proceedings on different grounds are under way, that disciplinary offences condoned by the employer with

5. Labour Standards Code R.S.N., 1973, c. 10, 8. 67(A) as am.

6. Described in F. Myers, Ownership of Jobs: a Comparative Study (1964), c. 3.

7. See Nipperdey, The Development of Labour Law in the Federal Republic of Germany Since 1945 (1954) 70 Int'1 Lab. Rev. 26, 148, 165.

8. Industrial Relations Act 1971, c. 72, s. 22 (repealed). See new Trade Union and Labour Relations Act 1974, c. 52, schedule I, part 2, as am. by the Trade Union and Labour Relations (Amendment) Act 1976, c. 7 and the Employment Protection Act 1975, c. 71. See generally S. D. Anderman, Unfair Dismissals and the Law (Institute of Personnel Management, 1973); J. McGlyne, Unfair Dismissal Cases (Butterworths, 1976); Jackson, supra, n. 2. For a useful review of the 1975 E.P.A. amendments, see article by Freedland. (1976) Mod. L.R. 561 .

9. See Svenska Arbetsgivare Foreningen, An Act Concerning Employment Security in Sweden, Document No. 15025 (1974).

10. Reports VII(1) and VII(2); Recommendation No. 119 on Termination of Employment at the Initiative of the Employer.

11. See generally, Industrial Relations Procedures, Dept. of Manpower Paper No. 14 (H.M.S.O., 1975), c. 5; Industrial Relations Code of Practice (H.M.S.O., 1972), articles 45-46. Articles 130-133 have been replaced by a new Code of Practice on Disciplinary Practice and Procedures in Employment, which came into effect on June 20, 1977, supra, n. 3; Brown and Beatty, Canadian Labour Arbitration (1976), c. 7. 
knowledge are no justification for dismissal, that equal treatment apply in respect of the same infraction, and that the penalty must fit both the offence and the offender, which necessitates considering any mitigating circumstances such as the employee's prior work record, the gravity of the infraction, the consistency with which the rule in question has been applied previously, and the degree to which the rule is known to the employee. It is implicit in the latter aspect of "fairness" that the umpire has discretion to substitute lesser penalties, including reduction of compensation, to take account of conduct by the employee which, though it does not justify dismissal, nevertheless entails some degree of "blameworthiness" on his part.

The second procedural safeguard is the prevailing philosophy that industrial discipline be corrective rather than punitive. This philosophy, parallelling rehabilitation theories in criminal law, sees the function of discipline as being primarily educative in affording the employee encouragement and opportunity to "mend his ways" and so become a "useful" member of the work force. Certain procedural safeguards are implicit in this approach, first, that rules of the work place should be unequivocal and expressly made known to the employee, especially if and when they are amended. Ideally the rules should specify which infractions will result in dismissal. Secondly, sanctions should be applied "progressively" so that the first transgression might invoke an oral or written warning, the second a suspension, and only in the last resort dismissal. The employee must be given clear warning that dismissal will follow unless his performance improves. Only where the evidence demonstrates that the employee would not have "corrected" himself given the chance to do so, or where there is misconduct of an exceedingly serious nature should "progressive" sanctions be dispensed with. In the absence of prior warnings and sanctions the employee is lulled into a false sense of security that his performance is satisfactory so that it would be unjust to "spring" dismissal on him. Thirdly, the onus of proving a justifiable dismissal should be on the employer who is in the best position to adduce reasons within his personal knowledge. Fourthly, the dismissal should not take effect until its justification is established. This requires that the "status quo" be maintained in that the worker is not penalized in the hiatus period. Suspension is permissible for bona fide protective purposes, for example, if the employee's continuation in the job jeopardizes safety or seriously disrupts operations, but it should be at full pay because the "corrective" model does not acknowledge the punitive role of imposing sentence before trial. Fifthly, previous sanctions applied to an employee must be struck from his record after he has worked satisfactorily for a certain period. "Wipe the slate clean" provisions are a common feature of criminal law rehabilitation schemes. ${ }^{12}$

One problem with the above-mentioned procedural safeguards is that they adopt a "management perspective" of discipline. The procedural desirability of a disciplinary code specifying work rules and penalties for their breach begs the question of who should determine its content. The tacit assumption is that this is a management "prerogative". Thus management unilaterally decides the "when and if" of dismissal, for instance, by fixing the standards of competence and behaviour or by declaring redundancies rather than cutting shareholders' dividends, and 
this is "fair" provided that it complies with procedures. It is submitted that "fairness" must be judged in terms of substance, that is, are the rules themselves "fair" and are they administered "fairly"? There is growing recognition in Western Europe and Canada that persons who will be substantially affected by decisions made by social and political institutions must be involved in the making of those decisions. ${ }^{13}$ For those accepting that philosophy, dismissal would be "unfair" unless workers themselves share equally in the formulation of plant rules and business decisions which result in dismissal. This does not negate management's "right" to command, which is essential to industrial organization, but merely questions the authorship of the orders which must be obeyed. Presently, and perhaps not surprisingly, no existing unfair dismissal legislation gauges "fairness" in this way. The practical implication is that "procedure" orientated unfair dismissal legislation may not make dismissal more difficult, so long as the procedures are observed; rather, it may make it easier because procedural "fairness" is seen to be done!'14 Even if bilateral worker/management rule-making is not made a requirement of "fairness", at least the independent umpire should be allowed to consider the "reasonableness" of management's rules and business decisions in substantive terms.

A second and related problem is the role of workers in the internal dismissal procedure. The seriousness of dismissal makes it desirable that the sanction be imposed not by the foreman or supervisor who initiates proceedings, but by a higher level management authority not previously involved in the dispute. The employee should also have the right to state his case at that level before the sanction is applied. However, to restrict the appeal to management is undesirable as management can hardly be expected to judge the reasonableness of a dismissal except by its own perception of the criteria involved in such an evaluation, namely by reference to economic "efficiency". High level management may be too remote from the actual practices of shop floor relationships to accurately assess workers' expectations, so that they are more likely to rigidly apply the formal rules than to take cognizance of "custom and practice" (which may have acquired legitimacy status at shop floor level). Further, higher management may be guided subconsciously by the need to maintain "managerial solidarity" so as to cause a reluctance to overrule decisions by lower level authorities. It is submitted that procedural "fairness" necessitates the formal participation of worker representatives at the appeal level whose function is to act as advocate for the employee, not as "co-judges" with management. This parallels the position under "just cause" articles in collective agreements, where dismissals are "bargained" by union and management in the grievance procedure before resorting to arbitration. This assumes that workers should have a voice in the formulation of the entire dismissal procedure, not that it be imposed unilaterally by management.

The third qualification of the "procedural" perspective of "fairness" is that certain substantive grounds for dismissal are so contrary to the public interest that dismissal will be automatically unfair. These include the prescribed grounds of "no discrimination" currently outlawed by human rights and labour relations legislation, but should also encompass

13. This underlies the Report of the Committee of Inquiry on Industrial Democracy (Bullock) (H.M.S.O. 1977). Cmnd. 6706 .

14. There is some evidence that this occurred in the U.K. See Weekes, Mellish, Dickens and Lloyd, Industrial Relations and the Limits of the Law (Blackwell, 1975), 23-24. 
other grounds considered obnoxious by the international community and public opinion, notably political views, sexual orientation, and family relationship. In addition to these attributes of "fairness", unfair dismissal legislation should have the following features:

First, the remedies must compensate the unjustly discharged employee for his actual financial loss, and not be restricted by an arbitrary "ceiling" on damages nor a contractual notice period. In particular, compulsory reinstatement must be available, although there are circumstances when it would be impracticable, for example, in an unfair redundancy dismissal where the job has disappeared.

Secondly, there should be provision for neutral conciliation prior to determination by the umpire in order to encourage voluntary settlement and "vett" frivolous claims. This would minimize the potentially deleterious effect of legal proceedings on work place relations and make reinstatement more acceptable than if personal relationships were irreparably "soured" by litigation. Moreover, conciliation would help to relieve the administrative burdens of a potentially enormous case-load.

Thirdly, the statutory protections should be available to all workers. There should be no qualifying period of employment whose purpose is to keep the case-load down. If this results in a flood of cases, the answer is to streamline the administration of the scheme. Indeed, evidence suggests that employees are more vulnerable to discharge in the early years of employment, ${ }^{15}$ and employers may be encouraged to dismiss immediately before the statutory protection is "triggered". Nor should protection be limited to workers under a "contract of employment", but should extend to those in a position of economic dependency on their "employer". Further, it is difficult to justify the exclusion of any particular "industry" from the statute, except where private procedures exist which are at least as favourable as those in the statute. The nature of given "industries", such as domestic service or the "family" firm, may make reinstatement impracticable, for example, where the facts clearly establish an irretrievable breakdown of interpersonal relationships, but it does not make inappropriate full compensation for an unfair dismissal.

Fourthly, the purpose of legislation is educative and preventative so that it should encourage the voluntary implementation of "fair" procedures. This involves formulating and publicizing standards of "fairness" in a Code of Practice, which is a government responsibility. The conciliation phase can also play a useful educative role, but since that depends on dismissal having been invoked, it is in a sense "too late". The English experience suggests that the enactment of the legislation accompanied by a Code of Practice did not encourage the introduction of procedures where they did not exist before. ${ }^{16}$ One solution is to create a "roving inspectorate" empowered to enter premises at their own discretion in order to evaluate existing procedures and suggest reforms. Failure to implement reforms should not invoke fines, as this may only "sour" work place relations, but could arguably be "punished" by doubling the amount of compensation paid to employees who are unfairly dismissed in the firm in question, and by withholding government contracts from the firm.

15. See Ross, The Arbitration of Discharge Cases: What Happens After Reinstatement (1957), Critical Issues in Labour Arbitration at 29. Ross' survey found that of 207 workers reinstated, only $18 \%$ had more than 10 years' seniority prior to discharge and $51 \%$ had less than 5 years' seniority.

16. Supra, n. 14 at $21 \cdot 23$. 
Fifthly, it is essential that dismissal procedures operate quickly, not only within the firm but also before the outside umpire; otherwise work place relations in general as well as the discharged employee may suffer. It is also important that proceedings before the umpire are relatively informal. In order that employees not be discouraged from taking their case to the umpire by reason of high expenses, legal aid should be available for the employee desiring legal representation, and the costs of the umpire should be borne by the government unlike arbitration under collective agreements where costs are nominally shared by the parties to the dispute, that is, union and management. It goes without saying that the umpire must be neutral and experienced in industrial relations. The latter is crucial, because legislated definitions of "fairness" must necessarily be vague. The most the statute could do is to incorporate or refer the umpire to a Code of Practice which must be worded generally since the circumstances of dismissal and local conditions vary enormously. For instance, the German legislation provides: ${ }^{17}$

'Socially unwarranted dismissal' means any dismissal not based on reasons connected with the person or conduct of the employee or on urgent service needs which preclude his continued employment in the undertaking.

Section 2(a) of the I.L.O. Recommendation 119 is even more vague:

Termination of employment shall not take place unless there is a valid reason ... connected with the capacity or conduct of the worker or based on the operational requirements of the undertaking . . .

Next, it is proposed to consider the extent to which the common law regulating dismissal satisfies these minimum standards of "fairness".

\section{THE POSITION AT COMMON LAW}

At common law, justification for dismissal is gauged in terms of rights and obligations under the employment contract. First, dismissal is unlawful as being in breach of contract where the employer does not give valid notice of termination in accordance with the express or implied provisions of the contract or if dismissal is in violation of disciplinary procedures which are incorporated expressly or impliedly into the contract. Further, the employer can terminate the contract without any notice or with less notice than that required, provided he gives proper wages in lieu thereof. It is uncertain whether this constitutes breach on the employer's part, in which case the wages in lieu operate as liquidated damages, or whether the employer has an implied contractual right to terminate at any time by giving wages in lieu of notice. However, summary dismissal without notice or wages in lieu is lawful where it is in response to a repudiation (anticipatory or otherwise) of the employment contract by the employee.

Secondly, dismissal is unlawful as being in breach of contract where the employee quits in response to a repudiation of the contract by the employer. This situation can be distinguished from wrongful dismissal in that the repudiation by the employer need not manifest an intention to terminate the employment relationship. Thus the employer may wish to maintain the employment relationship but on different terms, for example, at lesser wages.

Thirdly, where a statute expressly or impliedly imposes dismissal

17. Law of August 10,1951, An Act to Provide Protection Against Unwarranted Dismissals (1951) B.G.B.I. 499, 8. 1(2), translated in 1951 I.L.O. Legislative Series 1951 Ger. F.R.4. 
procedures and/or natural justice, dismissal in violation thereof is ultra vires, and therefore a nullity; in effect, there is no dismissal. So too, where natural justice is implied into the contract of an "office holder".

\section{A. Dismissal By Valid Notice of Termination}

At common law, provided the employer gives the requisite notice to terminate under the contract, dismissal is lawful notwithstanding that it is for an arbitrary, discriminatory or unjust reason. No legal formalities are required for a valid notice (unless the contract specifies otherwise), except that it must unambiguously and unequivocally manifest an intention to sever the relationship on an ascertainable date. There are no recent Canadian decisions which consider the effect of notice of improper form. There are three possible analyses. First, improper notice may be an offer to terminate which the employee accepts by leaving, in which case the contract ends lawfully by mutual agreement. Secondly, the employee may treat the improper notice as a repudiation and either quit upon receipt thereof or wait until it expires and claim wrongful dismissal if he is driven from the job. In the latter instances, the employee can recover damages, but they may be nominal since the employee may be regarded as having suffered no loss by reason only of the informality of the notice. Thirdly, the improper notice may be a nullity, in which case the employee who quits will have voluntarily terminated the relationship and may be liable in damages for breach if his resignation is not preceded by the requisite notice. In a recent English Divisional Court decision, ${ }^{18}$ notice that discharge for redundancy may arise at some future, unascertainable date, was held to be a nullity so that employees who quit to take other work were held not to have been dismissed for the purpose of entitlement to statutory redundancy payments.

The general rule does not apply where the contract is either for a fixed term, or specifies the form of notice, or the exclusive grounds on which it may be terminated. An example of the latter is McClelland v. Northern Ireland General Health Services Board, ${ }^{19}$ where the English House of Lords held by a majority of three to two that a "permanent and pensionable" contract expressed to be terminable only on named grounds could not be terminated lawfully by notice, for a non-specified ground. This decision has been challenged by the Trial Division of the British Columbia Supreme Court where Meredith J. held that an employment contract is always terminable by "reasonable" notice notwithstanding that it is expressed to be of permanent duration.20 Although the judge purported to find authority for this view in the judgments of Lords Goddard and Evershed, they did contemplate that a properly worded contract could be of permanent duration, but terminable in the event of repudiatory conduct by the employee. It may be that Meredith $\mathrm{J}$. considered it an unreasonable restraint of trade and therefore against public policy for an employer and an employee to contract to work together for life, ${ }^{21}$ but this is not stated in his judgment. In McClelland, it

18. Marton Sundour Fabrics Ltd. v. Shaw (1967) I.T.R. 84.

19. (1957) I W.L.R. 593 (HL).

20. Macdonald v. White Rock Waterworks (1974) 38 D.L.R. (3d) 763. In favour of this view see: Robinson v. Galt Chemical Products Ltd. (1933) O.W.N. 502 (Ont. C.A.); Savage v. British India Steam Navigation Co. (1930) 46 T.L.R. 294 (Wright J.); Ward v. Barclay Perkins Ltd. (1939) 1 All E.R. 287 (Oliver J.); G.W.R. v. Baxter (1922) 2 A.C. 1 at 25 per Lord Sumner. Contra: Salt v. Pouer Plant Co. Ltd., (1936) 3 All E.R. 322; Red Deer College v. Michaels (1975) 57 D.L.R. (3d) 386 at 399 per I askin CJ. (S.C.C.).

21. As in Milstead v. Hamp and Ross and Glendinning Ltd. (1927) W.N. 233 (Eve J.). One author suggests that the restraint argument should succeed where the employee cannot terminate, but not where the employer alone cannot terminate. Freedland, The Contract of Employment (O.U.P., 1976) 157. 
was open for the employee to terminate by six months' notice, unlike in Macdonald, and this may be a distinguishing feature to circumvent the restraint argument. However, that argument is not strong in Macdonald since the employee was only five years away from the retiring age specified in his contract, that is, seventy. Interestingly, the remedy in McClelland was a declaration that dismissal would be unlawful. The significance of this is considered later. ${ }^{22}$

The second requirement of a lawful notice to terminate is that its length must correspond with that required expressly or impliedly under the contract. ${ }^{23}$ This is a constant source of litigation in Canada because most contracts do not specify the notice period. There is a need for legislation requiring the employer to give written particulars of at least the central terms and conditions of employment, including notice periods, upon hiring or upon their subsequent modification. ${ }^{24}$ The prevailing uncertainty is especially tiresome in determining the contractual force of employee "fringe benefits" for the purpose of computing damages for wrongful dismissal. Moreover, compulsory notification of disciplinary procedures would reinforce their educative function. The law relating to the length of notice periods is vitally important for the employee since, along with the concept of "employee repudiation", it constitutes his exclusive measure of protection in the absence of unfair dismissal legislation.

The procedure for determining length of notice is as follows. ${ }^{25}$ First, is there an express term? Secondly, is there an implied term based on the parties' intention evidenced either by a custom or usage in the plant in question or a custom or usage in the trade or industry generally? Thirdly, and in the absence of the former, the court implies a term as to what it considers to be "reasonable" notice, which will often be at variance with the parties' intention (assuming they ever thought of it, which is often not the case). Fourthly, and overriding all others, notice must not be shorter than that required under employment standards legislation, although it may be longer. ${ }^{26}$

As to express notice periods, it seems that courts will construe strictly against the employer an express clause which purports to fix lesser notice than would be required by implication. Thus in Chadburn v. Sinclair Canada Oil Co.27 the clause read:

Either party may terminate this contract at any time, with or without cause. In the event of termination the employer shall not be liable to the employee for wages and salary, except as may have been earned at the date of such termination.

An employee who was given two days' notice to quit on the grounds of redundancy was held to be wrongfully dismissed because that clause, whilst restricting the right to wages, could not as a matter of construction be interpreted as ousting the common law requirement of "reasonable notice".

22. Infra, pp. $26-27$.

23. The minimum notice period under labour standards legislation cannot be reduced. For example, see Alberta Labour Act, S.A. 1973, c. 33, s8. 38 and 39 as am., but see the exceptions in Regulation No. 61 (1975), s. 2.

24. This is obligatory in the U.K. under the Contracts of Employment Act, c. 53, 1972, s8. $4-8$ as am. by the Employment Protection Act 1975, c. 71, Schedule 16, Part II.

25. Twamley v. Metcalfe Construction Co., (1944) 1 W.W.R. 54 (A.S.C., App. Div.).

26. Supra, n. 23. See O'Donovan v. Burns Foods Ltd. (1977), 73 D.L.R. (3d) 321 (Sask. C.A.); Baker v. Burns Bakery (1977) 74 D.L.R. (3d) 762 (Man. C.A.).

27. (1966) 57 W.W.R. 477 (A.S.C., Trial Div., Riley J.). See also Re African Assoc. Ltd. v. Allen, (1910) 1 K.B. 396. C.F. Doyle v. Phoenix lns. Co. (1893) 25 N.S.R. 436 (N.S.C.A.). 
In Allison v. Amoco Production Co., ${ }^{28}$ Macdonald J. interpreted a clause specifying 30 days' notice as merely constituting a "pre-notice" notice, in the sense that 30 days must expire before the common law "reasonable" notice period began to run, not that the contract would actually terminate after 30 days. Applying the rule of construction that where a clause is ambiguous, it is to be construed against the interests of the party for whose benefit it is included, he was able to give the employee 12 months' notice and correspondingly greater damages. It is highly doubtful that the clause was ambiguous and that the meaning attributed it by his Lordship reflected the intentions of the parties, but the case does demonstrate that, in the interests of "fairness" to the employee, very strong language is required to reduce the courts' conception of "reasonable" notice.

In order for custom or usage to form the basis for implication, the custom usage must be "reasonable, certain and known". There are no recent decisions of interest on this point. ${ }^{29}$

The recent cases on what constitutes "reasonable" notice suggest that the courts are manipulating the concept in order to do "fairness" to the employee, given the circumstances of his dismissal and his anticipated loss. In a sense, "fairness" is brought in through the back door under the guise of "reasonable" notice. Unlike in the United States, it is established that "hiring at will", whereby the employer can lawfully terminate without notice, does not represent the law in Canada. ${ }^{30}$ The requirement of "reasonable" notice stems from the employer's implied promise to maintain some sort of "on-going" relationship, without which the employment contract would not have stability or continuity. Further, the courts have historically recognized the policy justification of "cushioning" the employee while he seeks other work. Unfortunately, courts in the past have tended to award lengthier notice periods in the case of "higher" status occupations on the questionable assumption that the blow of unemployment falls heavier on those persons than on the "inferior" classes. ${ }^{31}$ However, recent decisions emphasize that not only is paramount weight to be attached to the availability of alternative work in determining "reasonable notice", but also that the low-status employee will be entitled to twelve months' or more if the labour market is unfavourable for him. ${ }^{32}$ Given that the worker's attractiveness in the labour market is now of overriding importance, ${ }^{33}$ the traditional attributes of the status, salary and responsibility of the job are now of secondary concern, though still relevant. ${ }^{34}$ Thus, Kirke-Smith $\mathrm{J}$. in the British Columbia Supreme Court, Trial Division, ${ }^{35}$ has taken judicial notice of industrial psychologists' evidence as to the serious problems facing redundant middle-aged executives in the labour market, saying:

28. (1975) 5 W.W.R. 501 (A.S.C., Trial Div.).

29. The older cases are noted by Harrison, Termination of Employment (1972) 10 Alta. L.R. 250 at 267.

30. The US.A. position is described in Summers, Individual Protection Against Unjust Dismissal (1976) 62 Va. L. Rev. 481 at $484-491$.

31. Morrison v. Abernathy School Bd., (1876) 3 Sess. Cas. 945 at 950 per Lord Deas.

32. Thiessen v. Leduc, (1975) 4 W.W.R. 387 at 400 per Macdonald J. (A.S.C.. Trial Div.); Wrighe v. Bd. of Calgary Auxiliary Hospital (1971) I W.W.R. 532 at 533 per Cullen J. (A.S.C., Trial Div.).

33. See for example, Paterson v. Robin Hood Flour Mills (1969) 68 W.W.R. 446, esp. 447 (B.C.S.C.), Trial Div.); Macdonald v. White Rock Waterworks (1974) 38 D.I..R. (3d) 763 (B.C.S.C., Trial Div.); Carey v. Drexel (1974) 4 W.W.R. 492 (B.CS.C., Trial Div.); Chadburn at 486, supra, n. 27; Thiessen v. Leduc, (1975) 4 W.W.R. 387, esp. pp. 339-400 (A.S.C., Trial Div.); McGuire v. Wardair Canada (1969) I W.W.R. 705 (A.S.C., Trial Div.); Baker v. Burns Bakery, supra, n. 26.

34. Status was emphasized in Gordies Auto Sales v. Pitre (1977) 73 D.I.R. (3d) 559 at 563 per Hughes C.J.N.B. (N.B.C.A.); Gillespie v. Buckley Valley Forest Inds., (1973) 6 W.W.R. 551 (B.C.S.C., Trial Div.).

35. Paterson v. Robin Hood Flour Mills, supra, n. 33 at 447. 
... it seems to me that in this area of human affairs (redundancy) the law must move perhaps more rapidly than it sometimes does in an effort to achieve a reasonable degree of conformity to the practical realities of commercial life.

In light of the employee's mature age and the unavailability of similar work, fifteen months' notice was held to be "reasonable". In another case involving a redundant middle-aged executive, Hinkson $J$. in the same court held fifteen months to be "reasonable" chiefly because no advance warning of redundancy had been given in order to enable the employee to "cushion" the blow. ${ }^{36}$ In contrast, a sixty-three-year-old worker currently in receipt of a pension from a previous employer who was wrongfully dismissed, was only entitled to six months' "reasonable" notice because the need to "cushion" the blow was not present. ${ }^{37}$ In addition, the courts take account of the employee's prior service record in respect to how long he has been employed and the quality and dedication of his service. ${ }^{38}$ The frequency at which wages are paid has rightly almost disappeared as a relevant consideration, ${ }^{39}$ whereas the ancient presumption of a yearly hiring is clearly dead. ${ }^{40}$ The modern trend of determining "reasonable" notice therefore tacitly recognizes that the employee should be dismissed "fairly" in the limited sense of having a financial "cushion" against loss of job, especially in a redundancy situation, and to this extent is to be welcomed. However, since "reasonableness" must be determined at the date of judgment, according to the circumstances then prevailing, the employee cannot predict his date of dismissal in advance and make plans for securing alternative employment. The financial "cushion" does ease his lot, but he may have missed opportunities by the absence of advance warning.

The effect of giving shorter notice than that required to lawfully terminate is that the employee can either quit and sue for damages at the date notice is given (anticipatory breach by the employer) or wait until the notice expires to sue for damages. Dismissal without notice is only lawful where the employee repudiates the contract. This is considered later.

\section{B. Dismissal by Wages in Lieu of Notice}

This is generally regarded as not amounting to wrongful dismissal. The legal status of wages in lieu is, however, uncertain. One view sees wages in lieu as liquidated damages for a technical breach of contract by the employer. Since the damages recoverable by the employee would be limited to the notice period and specific performance is unavailable, it would not be worth his while suing. This probably explains the paucity of jurisprudence on the point. On the other hand, some decisions suggest that the employer is entitled to lawfully terminate by giving wages in lieu by virtue of an implied term in the contract which springs from his right to terminate by proper notice. Under this approach there is no breach and the wages are payable as money-debt instead of as damages. It may be important both in practice and in theory whether a breach exists. First, breach could give rise to tortious liability for inducing breach of contract. Secondly, if the contract obliges the employer to provide actual work as

36. Carey v. Drexel, supra, n. 33.

37. Macdonald v. White Rock Waterworks, supra, n. 33. See also Tyrell v. Alltrans Express Ltd. (1976) 66 D.L.R. (3d) 181 (B.C.S.C., Trial Div.).

38. McGuire v. Wardair Canada; Carey v. Drexel, supra, n. 33.

39. With the exception of Gillespie, supra, n. 34, none of the recent cases even refer to it.

40. Richardson v. Koefed (1969) 3 All E.R. 1264 (C.A.). 
well as wages, the worker could sue to recover extra damages over and above wages. This may become important in Canada if Lord Denning's reasoning that there is an implied contractual "right to work" is followed, ${ }^{41}$ and for those exceptional categories of worker whose contracts impliedly entitle them to actual work. ${ }^{42}$ Thirdly, the presence of a technical breach of contract may have important taxation implications. ${ }^{43}$ Fourthly, it is strongly arguable that an employee has a general interest in continued working, if not a "right to work" in the Langston sense. Fifthly, it is questionable policy that the employer be allowed to benefit himself by removing the worker from the job in contravention of his basic undertaking, under the employment contract, to maintain the employment relationship for a certain period of time.

The English cases do not decide clearly which view represents the law. In the most recent, Sir John Donaldson said at one point that the employer has no contractual right to impose wages in lieu of notice but rather an unqualified power to terminate summarily the contract and pay liquidated damages forthwith. ${ }^{44}$ Yet later in his judgment he seemed to imply that the employee who receives wages in lieu may be on paid leave, which suggests there is no breach. The earlier English authorities are equally inconclusive, some suggesting that it depends on a construction of the contract, ${ }^{45}$ others suggesting that there is no breach ${ }^{46}$ and some being non-committal. ${ }^{47}$ The Canadian law is equally inconclusive. In Gillespie, ${ }^{48}$ Berger J. in the Trial Division of the British Columbia Supreme Court held obiter that the employer is contractually entitled to dismiss on the spot by wages in lieu of notice, whereas Batten D.C.J. in the Saskatchewan District Court found the opposite, again obiter. ${ }^{49}$ In neither decision were authorities referred to nor analysis undertaken. It is submitted that in order to be consistent with the theory of the employer's implied promise of "on-going" employment, dismissal should be in breach where wages in lieu are paid. This would also protect the special interest of workers enjoying a contractual "right to work" and prevent the employer from gaining an undeserved windfall by deducting taxation from wages in lieu.

\section{Repudiation by the Employee: the Right of Summary Dismissal}

The employer's right to terminate forthwith in response to a repudiatory breach by the worker is now a generally accepted example of the general contract law principle that the innocent party can accept a repudiation as bringing the contract to an end and sue for damages. ${ }^{50}$ Employers rarely sue for damages as the amount recoverable is generally minimal, but the law reports abound with cases where employers seek to justify dismissal "on the spot" or with insufficient notice by claiming that

41. Langston v. A.U.E.W. (1974) 1 All E.R. 98. (C.A.). See also Breach v. Epsylon Inds. [1967] 1 R.L.R. 180 (E.A.T.); Bosworth v. Angus Jowett Co. [1977] I.R.L.R. 374 (I.T.).

42. Infra, p. 21

43. It is beyond the scope of this article to discuss the ramifications of $R$. v. Atkins (1976) C.T.C. 497 (F.C.A.). See Krishna, Characterization of Wrongful Dismissal Awards for Income Tax (1977) 23 McGill L.J. 43.

44. Dixon v. Stenor (1973) 1 C.R. 157 (N.I.R.C.).

45. White v. Riley (1921) $1 \mathrm{Ch}$. 1.

46. East Anglian Rlwy. Co. v. Lythgoe (1851) 10 C.B. 726.

47. Austwick v. Midland Rlwy Co. (1909) 25 T.L.R. 728.

48. Supra, n. 34.

49. Carson v. Dairy and Poultry Pool (1966) 56 W.L.R. 629 at 633.

50. This underlies Pepper v. Webb (1969) 1 W.W.R. 514 (C.A.) and Laws v. London Chronicle (1959) 1 W.L.R. 698 (C.A.). Historically, the right did not originate from general contract law. See Hepple and O'Higgins, Encyclopedia of Labour Relations Law Vol. I, para. 1-341 (Sweet and Maxwell, 1977). 
the employee repudiated the contract. ${ }^{51}$ In a sense, therefore, the concept of employee repudiation is the "just cause" of the common law.

The test for determining whether acts of misconduct or disobedience by an employee justify summary dismissal has progressed from the harsh position whereby misconduct, neglect and disobedience were regarded as virtually automatic grounds for dismissal. This arose from the courts treating breach of employment contracts as sui generis, distinct from general concepts of repudiation. Modern cases have brought employee repudiation within general contract law principles, so that the former "specific" rules relating to misconduct, neglect and disobedience are now subsumed under the two general requirements that a repudiatory act must violate an "essential" condition of the contract and must be incompatible with the continuance of the employment relationship. ${ }^{22}$ This test enables the courts to consider the importance of the breach in the context of the relationship as a whole and to tailor their decisions more and more to prevailing standards of industrial "fairness". However, courts continue to treat incompetence in the traditional fashion whereby it justifies dismissal on the ground that the employee has broken an implied promise that he can perform competently. This approach looks back to the formation of the contract rather than prospectively to the future likelihood of satisfactory performance. Where the employee has obtained employment by fraud or misrepresentation, dismissal is justified. However, insofar as incompetence is attributable to defective selection and training techniques by management, or to the worker's inability to perform new tasks pursuant to technological change, it is "unfair" that he be dismissed on the basis of such an implied undertaking. Recent decisions suggest that courts are tempering this theory and accommodating standards of "fairness" by looking for possibilities of future satisfactory performance.

The tests outlined above give the judge considerable discretion to accommodate prevailing standards of "fairness", so that older authorities will become relatively insignificant. As Edmund Davies L.J. said in a recent English Court of Appeal decision: ${ }^{33}$

Reported decisions provide useful, but only general guides, each case turning upon its own facts. Many of the cases which are customarily cited date from the last century and may be wholly out of accord with current social conditions. What would today be regarded as almost an attitude of Czar-serf, which is to be found in some of the older cases ... . would I venture to think be decided differently today. We have by now come to realize that a contract of service imposes upon the parties a duty of mutual respect.

In Camille Albert Rivest v. Canforge Ltd. ${ }^{54}$ the plaintiff, who was employed as vice-president and manager of a concrete company in Calgary, was summarily discharged for unauthorized absence from work for five days. The evidence was that the plaintiff was under intensive pressure at work caused by the company over-committing itself and that this caused him nervous tension, loss of memory and appetite, and insecurity which resulted in his hospitalization. In holding dismissal to be unlawful, Bowen J. emphasized the business pressure and the employee's medical condition as factors mitigating his absence, especially

51. In Carson, supra, n. 49, Batten D.CJ. suggests that the employer cannot dismiss summarily for repudiations committed before the expiry of a previously given notice of discharge. This is incorrect.

52. It follows that redundancy is not "just cause" for dismissal. Western Mines v. Childs (1975) 51 D.L.R. (3d) 145 (B.C.S.C., Trial Div.); Paterson, supra, n. 33.

53. Wilson v. Racher, (1974) I.C.R. 428, at 430.

54. Unreported decision of the A.S.C., Trial Div., Bowen J. 9th May, 1977. 
in view of his long and commendable prior service record. The judgment is couched in terms of arbitral "just cause" standards rather than in terms of repudiation (indeed, no authorities are cited and his Honour refers to "cause" instead of "repudiation"). The following quote illustrates the importance given to "fairmess" standards in the decision.

The taking over of smaller individual companies by conglomerates is a common phenomenon in this country today. Such acquisitions, however, change the whole atmosphere of the acquired company and in this instance it was obvious that this was the case. It is my view that ordinarily such conglomerates with acquired companies have an utter disregard for the human frailties which are extant from time to time amongst employees of the companies and it is my view further that that is exactly what happened in this instance. The plaintiff had given 19 years of exemplary service to the company. As a result of things beyond his control in the spring of 1974 he was placed in a position of strain and tension that occasioned an illness on his part. If his superiors had taken the time in June of 1974 to assess the situation from a reasonable and understanding point of view undoubtedly he would have been placed on a leave of absence for sickness until he was able to return to work.

All of the evidence and the factors involved lead me to the one inescapable conclusion that the defendant discharged the plaintiff without cause.

In Robert Riley v. Crown Trust Co.,55 the plaintiff was held to be lawfully dismissed on grounds of persistent bad time-keeping. Macdonald $J$. emphasized the fact that the employee had been warned to improve on two previous occasions, and on a third had been told that further lateness would result in his dismissal. The employee had therefore been afforded ample opportunity to mend his ways. Accordingly, his persistent lateness amounted to repudiation in the sense of disobediance to a lawful and reasonable order within the classic formulation of Lord Evershed in Laws v. London Chronicle. ${ }^{56}$ Not only did Macdonald J. manifest a welcome awareness of procedural "fairness", but by considering the importance of prompt time-keeping on work place relations and work organization in general, his Honour was clearly concerned that the substance of the employer's decision be "fair".

In Macdonald v. White Rock Waterworks ${ }^{57}$ an employee who spoke "demeaningly" of the Board of Directors upon being informed that his retirement date was to be brought forward five years, was held to be wrongfully dismissed. Meredith J. said that a single instance of abusive words in a moment of anger does not constitute sufficient disobediance to warrant summary dismissal. In contrast, the English Court of Appeal in Pepper v. Webb $b^{58}$ held that a gardener who, after a quarrel with his employer, an ex-army major, said: "I couldn't care less about your bloody greenhouse and your sodding garden", had repudiated his contract so as to justify summary dismissal. Lord Karminski seemed to revert to the traditional rule that any wilful disobedience of a lawful order justified dismissal. Harman and Russell L.L.J. took the more realistic approach that dismissal was justified because the employee had committed numerous acts of disobedience in the recent past against which the outburst in question had to be judged.

This trend is also evident in the incompetence cases. In Manning v. Surrey Memorial Hospital,,$^{59}$ a chief administrator was discharged for inadequately maintaining the accounts. Munroe J. held the dismissal to

\footnotetext{
55. Unreported decision of the A.S.C., Trial Div., Macdonald J. 23rd June, 1977.

56. Supra, n. 50.

57. Supra, n. 33.

58. Supra, n. 50.

59. (1975) 540 D.L.R. (3d) 312 (B.C.S.C., Trial Div.).
} 
be unlawful because no previous warning had been given to the employee to enable him to improve his performance. In Hayes v. Eastman Oil Well Survey Co. Ltd.,60 a sales manager with a drinking problem exacerbated by the "convivial" context of selling was promoted to district manager on a six month trial basis. The employer knew of his problem and it was hoped that the promotion, involving less sales contact, would help eradicate it. When the problem had not improved after six months, he was summarily dismissed. Milvain C.J. held there to be wrongful dismissal, applying a test which owes more to arbitration than to contract laws of repudiation:

Under these circumstances, the court is required to determine whether or not this was a proper discharge for cause ... In measuring what is reasonable, the court has to take into consideration all of the circumstances that surround the employment in determining whether or not a reasonable course has been taken. It seems to me, and I think it to be the law, that there is an employee who has been in employment for a long time, he should be warned that unless he mended his ways he would be discharged, where his ways have been known and recognized for some time . . . he should be given a reasonable time within which to reform himself.

His Honour was not prepared to construe the probationary nature of the position as an implied warning, but that an explicit warning that dismissal would be invoked failing improvement was required. Significantly, no authorities on repudiation were cited in the judgment. In these cases, the courts are exercising their discretion under the vague "repudiation" test to effectuate the policy of corrective discipline.

A more realistic application of the test is also evident in the recent decisions on the employee's duty of fidelity. The Supreme Court of Canada as recently as 1961 formulated as the basis of repudiation in cases where the employee commits a fraud on his employer, that the employer cannot thereafter have that confidence in the worker's trustworthiness and integrity required for an employment relationship. ${ }^{61}$ However, in Hardie v. Trans-Canada Resources, ${ }^{62}$ the Appellate Division of the Alberta Supreme Court held that a sales representative fired for making irregular expense claims in order to avoid income tax was wrongfully dismissed, although McDermid J.A. admitted that he reached the decision "with some hesitancy". The court considered that since the employee did not intend to cause financial injury to his employer and no such injury was in fact sustained, it did not matter for the purposes of determining a repudiatory breach that the employee illegally swindled the taxation authorities. However, had the employee been an accountant, discharge would have been justified. This can be distinguished from Portland Cement in that there the worker perpetrated the fraud on his company, but one questions whether the underlying principle should not extend to this situation, not the least because salesmen have considerable exposure to financial dealings. Surely, illegal tax evasion comes very close to manifesting a lack of integrity that could be said to carry over and threaten the trustworthiness of the worker vis $\dot{a}$ vis his employer. Another distinguishing feature of this case seems to be that the company president knew of and condoned the swindle. Two of the judges said this was irrelevant on the ground that the board of directors and shareholders did not know of the swindle so that the company could not be said to have

60. Unreported decisions of the A.S.C., Trial Div., Milvain C.J., 16th February, 1976.

61. Lake Ontario Portland Cement Co. v. Groner (1961) 28 D.L.R. (2d) 589 (S.C.C.).

62. (1977) 71 D.L.R. (3d) 668 (A.S.C., App. Div.). 
condoned it. However, for the employee the president surely has an apparent authority to bind the company, at least unless the employee knows that he is on a "frolic of his own". This element arguably makes discharge "unfair" on the facts, but the case demonstrates how widely the gap is growing between older repudiation authorities and current concepts of "fairness".

As welcome as these trends are, it is submitted that the repudiation concept is nonetheless unsatisfactory as a device for assuring "fair" dismissals, for several reasons. First, the common law has no predictive function whereby standards are set as guides for the parties' future conduct, unlike collective agreements and "fair" dismissal Codes of Practice. This is inevitable since the courts do not intervene until after relationships have broken down.

Secondly, judges do not have their fingers on the industrial relations pulse as do labour arbitrators, and so may not always reach decisions that reflect good industrial practice. In addition, the expense, delay and formality of litigation are disadvantageous.

Thirdly, there are certain wellestablished common law principles which are blatantly inconsistent with "fairness" but which the courts, irrespective of their desire to see justice done, might find difficult to circumvent. The most indefensible is that, with few exceptions, ${ }^{63}$ the employer is not obliged to comply with "natural justice". No reason need be given to the worker, nor is he entitled to state his case or appeal his employer's decision. These traditional attributes of "natural justice" do not go all the way in guaranteeing an "ideal" dismissal procedure, but they surely represent minimum acceptable standards. Moreover, the employer is entitled to lawfully discharge without notice on unjustifiable or even non-existent grounds provided that by the time of trial he has unearthed a justifiable offence, which may have committed either before or after the dismissal.64 Thus, if the employee is summarily discharged for a provocative reason and responds by attacking his employer, the employer may rely on that attack to justify his originally wrongful dismissal! This rule was approved by the Supreme Court of Canada in 1961.65 It is tempered somewhat in that the empoyer cannot rely on a previous repudiation which he has knowledge of and expressly or impliedly condones, although such "waived" breaches can be taken into account in conjunction with a new non-condoned repudiation, which "triggers" the employee's past work record, for the purpose of establishing a "repudiatory" pattern of conduct warranting discharge.66 Even if "fair" procedures governing dismissal are expressly incorporated into the contract, the employee's only remedy for violation thereof is damages.

The exceptional circumstances where procedures to govern dismissal are required at common law are: first, where the statute specifies the procedures to be observed, secondly, where statute governs the employment relationship and "natural justice" may be implied from the statute, and thirdly, where the employee is also an "office-holder".

63. See para. immediately following footnote.

64. Lake Ontario Portland Cement, supra, n. 61; Boston Deep Sea Fishing and Ice Co. v. Ansell (1888) Ch.D. 339 (H.L.).

65. Portland Cement, supra, n. 61.

66. O'Callahan v. Transair Ltd. (1975) 58 D.L.R. (3d) 80 at 87 per Guy J.A. (Man. C.A.); Lucas v. Premier Motors (1928) 3 W.W.R. 193 (A.S.C., App. Div.). In Empey v. Coastal Towing Co. [1977] 1 W.W.R. 673 (B.C.S.C., Trial Div) it was held that three weeks between the employer becoming aware of the repudiation (employee "betrayed" his employer to a competitor) and the dismissal did not constitute condonation by the employer since three weeks was a "reasonable" period in which to investigate the alleged misconduct. 
An example of the first situation is Placsko v. Board of the Humboldt School Unit \#47 of Saskatchewan ${ }^{67}$ where a teacher was dismissed for redundancy when the statute regulating her employment stated that teachers could only be dismissed on grounds of unsuitability. MacPherson $J$. granted a declaration that the purported dismissal was ultra vires the employer and therefore a nullity, so that she had not been dismissed in the first place. The implications in respect to remedies are considered later.

Secondly, the presence of a statute may operate to imply "natural justice". Thus in a recent English House of Lords decision, teacher was discharged without being given the right to be heard before the General Teaching Council, a body charged under the Education Act with hiring and firing. The Act required the Council to give three weeks' notice of hearing to the employee, but it did not expressly entitle him to present his case to the Council. Their Lordships by a majority of three to two held that the right to present a case was implied by the statutory obligation on the Council to give notice of the hearing, for otherwise that obligation would serve no purpose. Accordingly, the dismissal was "reduced" 69 as being ultra vires the Council and therefore a nullity. This contrasts with $R$. v. Bird ex parte Ross ${ }^{70}$ where a fire chief whose employment was governed by statute requiring a dismissal hearing by the employing body, was discharged without being given the right to answer charges against him, the right to legal representation, adequate time to prepare his defence, nor was he present when vital evidence was adduced against him. McInnes J. refused to imply "natural justice" from the statutory establishment of a hearing body because first, that would "inconvenience" the hearing and, secondly, specific performance would be unavailable to maintain the employment relationship. With respect to the former ground, one might ask "inconvenient for whom?" The second ground misses the point that the employment contract would never have terminated because discharge would be a nullity. As Lord Reid said in rejecting the specific performance obstacle in Malloch:71

But that (specific performance) would not be the effect. There would be no reinstatement. The result would be to hold that the appellant's contract of employment had never been terminated and it would be open to the respondents at any time hereafter to dismiss him if they chose to do so and did so in a lawful manner. Unless they chose to do that the appellant's contract of employment would continue . . . in my view if an employer fails to take the preliminary steps which the law regards as essential he has no power to dismiss and any purported dismissal is a nullity.

In the latest case in point, Abouna v. Foothills Provincial Hospital Board,72 MacDonald J. reverts to the Malloch view. The facts were that the plaintiff, a renowned surgeon, was dismissed by the Board pursuant to a recommendation of the Medical Advisory Committee at which he was given no opportunity to appear or be heard and without notice of the hearing and charges against him. The Board was established by the Provincial General Hospitals Act and empowered to make by-laws governing hospital administration, including hiring and firing. The by-

67. (1971) 18 D.L.R. (3d) 374 (Sask. Q.B.). See also Hospital Sainte Jeanne d'Arc v. Garneau (1961) S.C.R. 426 (S.C.C.).

68. Malloch v. Aberdeen Corporation (1971) 2 All E.R. 1278.

69. "Reduction" is the Scottish declaration.

70. (1963) 38 D.L.R. (2d) 354 (B.C.S.C., Trial Div.).

71. Supra, n. 19.

72. Unreported decision of the A.S.C., Trial Div., Macdonald J., 6th August, 1977. 
laws provided that dismissal by the Board must be preceded by a recommendation from the M.A.C., although the Board was not bound to implement such recommendation. Further, the judge interpreted the bylaws (which are somewhat ambiguous) as requiring that where a recommendation for discharge is brought before the M.A.C., the employee concerned must be notified of his right to appeal and be entitled to present his case to the M.A.C. before it made a recommendation to the Board. The plaintiff sought a declaration that his dismissal was a nullity in order to retain his job. MacDonald J. held the dismissal to be void and awarded damages only. ${ }^{73}$ His Honour seemed to base his decision on two grounds.

First, he treated the by-laws as a form of statutory regulation of the employment relationship, and construed them as inposing the right to appeal and present argument to the M.A.C. Contravention of these "statutory" requirements meant that the Board's dismissal, following an improper M.A.C. recommendation, was ultra vires.

MacDonald J.'s second ground constitutes the third exception to the rule against "natural justice", namely that an employee who is an "office holder" has a "property interest" therein which cannot be adversely affected save in accordance with "natural justice". Unlike the normal master-servant relationship, which confers exclusively contract rights, the additional presence of the "office" as a "property right" activates "natural justice". MacDonald J. appears to say that where a body exercises powers over an employee under statute, delegated or otherwise, and that body acts in a quasi-judicial role in that it adversely affects the interests of an employee, then the rules of natural justice automatically fetter the exercise of that power, unless the statute expresses otherwise. As with discharge in contravention of explicit "natural justice" standards in the statute, the purported dismissal is void. MacDonald J.'s judgment does not clarify the categories of employee deemed to be "office holders" beyond stating that their employer must derive his powers from legislation. In Malloch, Lord Wilberforce said: ${ }^{74}$

One may accept that if there are relationships in which all requirements . . of natural justice are excluded (and I do not wish to assume that this is inevitably so), these must be confined to what have been called 'pure master and servant cases' ... in which there is no element of public employment or service, no support by statute, nothing in the nature of an office or status which is capable of protection.

This is extremely vague. For instance, it is uncertain whether lower grades of public employee would be treated the same as the higher grades. It is true that in McClelland, ${ }^{75}$ the hospital clerk was granted a declaration but the court clearly regarded her employment as contractbased; the better explanation of the case may be that she was an "office holder" because her terms of employment were approved by the Minister, though this was not argued in the case. In any event, it is highly questionable that the features of public employment are sufficiently unique in real terms as to justify treating private sector employees in a less advantageous manner.

One potential problem with holding the dismissal of "office holders" and statutory regulated employees to be void is that technically there may be no "dismissal" for the purpose of unfair dismissal legislation, although

73. The Appellate Division of the Alberta Supreme Court reduced Abouna's damages to $\$ 10,000$ in a decision handed down immediately before this article went to press on January 27, 1978.

74. Supra, n. 68 at 1294.

75. Supra, n. 68 at 1284. 
this is by no means settled law. ${ }^{76}$ That may be disadvantageous to the worker where an "unfair dismissal" statute imposes stricter standards than "natural justice". To avoid this possibility, the statute should expressly provide for the coverage of such employees.

\section{Variation of the Contract By the Employer Resulting in Dismissal}

Here the employer does not want to sever the employment relationship, merely alter the terms under which it is to continue. In this sense it is distinguishable from the preceding situations, although technically the employee is unlawfully dismissed. The employer's unilateral amendment of an important term of the contract constitutes a repudiation (anticipatory when notice thereof is given) which the employee can accept by resigning and suing for breach. The thorny question is whether, by continuing to work on the new terms for a certain time, the employee loses his right to terminate and recover damages.

\section{Repudiation by the Employer}

A unilateral variation of a major term of the contract does not constitute a repudiation where such variation is expressly or impliedly permitted by the contract. This questions the scope of "management prerogative" under the contract. The courts have held that the employer has no implied contractual right to unilaterally withhold part of a salesman's commission, ${ }^{77}$ to transfer a police chief to a vaguely-defined public office with less job security, ${ }^{78}$ to withdraw an "expatriate allowance" normally payable only to U.S. persons working in Canada when the employee became a Canadian citizen, ${ }^{79}$ to refuse full payment of wages, ${ }^{80}$ to demote an employee to a lower status job ${ }^{81}$ and to impose a restraint of trade covenant during the currency of an existing contract. 82 Further, the English courts in interpreting the Redundancy Payments Act have held that there is no implied term permitting the employer to transfer the employee to work locations beyond reasonable commuting distance of home, unless the practice of the employment is that the employee has continually been moved about the country.83 In the recent case of Langston v. A.U.E.W., ${ }^{84}$ Lord Denning in the English Court of Appeal has potentially extended the ambit of employer repudiatory breaches by holding that:

... it is arguable that in these days a man has, by reason of an implication in the contract, a right to work. That is, he has a right to have the opportunity of doing his work when it is there to be done,

and Stephenson and Cairns L.J.J. hesitatingly agreed. The basis of such a right is the satisfaction which the employee gets from his job. Accordingly, the employer was in breach of contract by suspending the employee at full pay for the purposes of establishing the tort of inducing

\footnotetext{
76. It was suggested that there would be no "dismissal" for the purposes of the English legislation in Earl v. Slater and Wheeler (Airlyne), 1972 1 C.R. 508 (N.I.R.C.). Cf. DeSmith, infra, n. 129 and accompanying text.

77. Hill v. Peter Gorman (1957) 9 D.L.R. (2d) 124 (Ont. C.A.).

78. Thiessen v. Leduc, supra, n. 33.

79. Allison v. Aimco Production Co. (1975) 5 W.W.R. 501 (A.S.C.. Trial Div.).

80. Slater v. Moncton Electricity and Gas Co. (1946-47) 19 M.P.R. 261 (N.B.S.C., App. Div.).

81. O'Grady v. Insurance Corp. of B.C. (1976) 63 D.L.R. (3d) 370 (B.C.S.C., Trial Div.); Burton v. MacMillan Bloedel Ltd. (1976) 4 W.W.R. 267 (B.C.S.C., Trial Div.); Baker v. Burns Bakery, supra, n. 26, but contrast the dissenting judgment of Guy J.A.; Clark v. Faber et al., [1977] 6 A.R. 415 (A.S.C., Trial Div.).

82. Maguire v. Northland Drug Co. (1935) S.C.R. 412.

83. O'Brien v. Assoc. Fire Alarms (1968) I W.L.R. 1916 (C.A.).

84. Supra, n. 77 at 136.
} 
breach of contract on the part of the union which had threatened a strike unless the plaintiff, a non-unionist, was discharged. Previous cases established that the employer's consideration included the provision of work only in exceptional circumstances: where performers contract for "publicity"; 85 where a reasonable amount of work is necessary to enable workers paid by results to earn a fair wage; ${ }^{86}$ and where work is necessary for the employee to develop or maintain his skills. ${ }^{87}$ Thus disciplinary suspension at full pay, an integral aspect of "corrective discipline", cannot be invoked at common law. ${ }^{88}$ In addition, the employee who is dismissed with wages in lieu of notice can presumably sue for the loss of his "job satisfaction", provided that breach is involved in such a dismissal. It is difficult to escape the conclusion that damages would be nominal in the case of production line workers! Further, the English cases establish that there is no implied right to suspend the contract without pay in the absence of express provision or custom or usage in the plant to the contrary. ${ }^{89}$ Disciplinary unilateral suspension is therefore in breach and the employer is denied this attribute of "corrective discipline".

It is possible that a unilateral variation of a major term may not constitute repudiation where the employer gives notice of the requisite length that employment will be available only on changed terms. In effect, this is valid notice of termination coupled with an offer of reengagement on new terms. If the employee consents to the changes by continuing work, he is bound by a fresh contract. If he refuses, his dismissal is lawful. There is English authority supporting this approach. ${ }^{80}$ In a dissenting judgment in Hill v. Peter Gorman, Gibson J.A. in the Ontario Court of Appeal held that a salesman who had been informed that $10 \%$ of his commission would be "docked" by notice of greater length than that required to lawfully terminate his contract, and who continued to work on that basis for a further 16 months, could not sue for breach of contract to recover such monies. He viewed the notice of variation as lawful notice of termination coupled with an offer to reengage under the "docking" provisions which the employee accepted by continued work.91 Insofar as this approach involves the ending of one contract and the creation of another, it has implications on "continuous employment" for the purposes of unfair dismissal legislation incorporating that concept. Moreover, whereas the new contract clearly includes the altered terms, it may be debatable which terms of the original contract carry over into the second.

\section{Problems of Consensual Variation Where the Variation}

\section{Is Not Coupled with Lawful Notice to Terminate}

This situation occurs when the unilateral amendment is not preceded by equivalent notice as is required to terminate lawfully, but the employee continues in the job for some time and then quits. Can the employee treat the variation as a repudiation, leave without notice and sue for damages for breach? There are several possibilities.

First, the contract may be consensually varied, which assumes

85. Clayton and Waller v. Oliver, (1930) A.C. 209 (H.L.).

86. Devonald v. Rosser (1906) 2 Q.B. 728.

87. Re Rubel Bronze (1918) I K.B., 315 at 324.

88. Hanley v. Pease (1915) I K.B. 698.

89. Id.

90. Morgan v. Fry, (1968) 2 Q.B. 710 per Davis L.J. (C.A.).

91. Supra, n. 41 at 190. 
uninterrupted continuity of it. The major drawback with this view is that the employer does not appear to furnish extra consideration to support the change where the employee is notified that he must either accept it (and does so) or be wrongfully dismissed. The employer's forbearance to break the contract by wrongfully dismissing the worker is not valid consideration..$^{22}$ However, where the change is supported by an express or implied promise on the employer's part not to lawfully terminate the contract, his forbearance to exercise that legal privilege has been held as good consideration. ${ }^{93}$ It will be rare that an employee expressly or impliedly requests a disadvantageous amendment so as to create a unilateral contract. ${ }^{94}$

Secondly, if the employee's continued working and apparent consent to the change causes the employer to suffer detriment, e.g. by re-organizing the work place, the employee may be estopped from alleging repudiation. Thus, in Slater v. Moncton Electricity and Gas Co., an employee alleged the existence of an oral contract with his supervisor whereby his pay was to be brought up to that of other workers in his grade within a certain time. He was never given the increases, and on complaining to the departmental manager was told that no such contract had been concluded by the supervisor. He continued to work at the lower rate for four years and signed an acknowledgment every pay day that his wages were "full pay" for services rendered. The court rejected his claim for back pay under the alleged oral contract. One of the reasons was that the employee was estopped from asserting breach of the oral contract. The detriment sustained by the employer was retaining the plaintiff's services when, had the employer known of the extra wages continually accruing to the worker, he would have replaced him with another person who would have worked at the lower wage. One problem with this approach is that the party who is estopped is entitled, upon giving reasonable notice, to insist on his rights.

Thirdly, the parties may consensually rescind the contract and replace it with a fresh one containing the amended terms. An agreement to rescind generates its own consideration in that each party gives up its rights against the other under the original contract. ${ }^{96}$ This approach seems to underlie the reasoning on the majority in Hill v. Peter Gorman ${ }^{97}$ and was one of the grounds for the decision in Slater. ${ }^{98}$ However, given that the test for rescission is that the parties objectively manifest an intention to bring the contract to an end, 99 this is arguably only satisfied if the amendment is so significant as to change the nature of the job itself. 100 Arguably, reduction in wages only changes the nature of the job where the drop is significantly large. It may be important whether there

92. See Stoljar, The Modification of Contracts (1957) 35 Can. Bar Rev. 485, at 492.

93. Maguire v. Northland Drug Co., supra, n. 82 at 415 ; Peerless Laundry Cleaners v. Neal, [1953] 2 D.L.R. 494 (Man. C.A.); Corbin on Contracts (West Publishing Co., 1952, one volume edition), para. 135. In Camille Albert Rivest v. Canforge, supra, n. 54, a wrongfully dismissed employee was entitled to recover damages for the holiday he worked in 1973 on the basis that he had been compensated for working his holiday the previous year, notwithstanding that the custom in the firm was that holidays were not cumulative. This may be explicable in terms of consensual variation, but the court did not discuss the point.

94. See Higgins, (1974) Cambrian L.R. 36 for an interesting discussion of unilateral contracts.

95. Supra, n. 80 at 267.

96. Morris v. Baron Co. (1918) A.C. 1.

97. Per Mackay J.A., supra, n. 707.

98. Supra, n. 80 at 268.

99. "The distinction between a variation amounting to a recission followed by the making of a new contract and a simple variation appears to be one of degree". Treitel, Law of contract (Stevens, 1975), 72.

100. See Freedland, supra, n. 21 at 69. 
is a rescission in deciding which terms of the old contract carry over expressly or impliedly into the new contract and in determining "continuous employment". In addition, where the contract is for a fixed term of more than one year with no provision for earlier termination by either party, a rescission would presumably have to be in writing under the Statute of Frauds. ${ }^{101}$

Whichever approach is taken, it is clear that the employee must truly consent to the alteration, otherwise he is entitled to quit and sue for damages. A rather extreme example is Hill v. Peter Gorman where the worker continued under the alteration for 16 months, although he complained to his employer monthly when he received his pay, and this was held to negative consent. At the other extreme is Raypold v. MeEvoy Oilfield Services ${ }^{102}$ where an employee, summarily fired by a supervisor who also physically attacked him, remained on the job for 13 days, after having informed the employer that he considered himself discharged, during which time the employer was in negotiation with the employee's lawyer over acceptable terms of reinstatement. The ratio of the case was that the supervisor did not have authority to fire the employee (but surely he was justified in quitting on grounds of the assault, at least unless he provoked the attack). An alternative ground, however, was that his continuing in the job waived any breach that may have occurred. This seems harsh to the employee. Where the worker does continue after breach without true consent, it is probable that the arrangement is some form of "hiring at will". The English courts recognize that the employee should have a "trial period" in which to assess the changed terms before consent is found, and they also recognize that consent is often "Hobson's choice" between unemployment or suffering the disadvantageous amendments. Thus, Sir John Donaldson said:103

However, the courts have rightly been reluctant to find that there has been a consensual variation where an employee has been faced with the alternative of dismissal and where the variation has been adverse to his interests

Consent rightly seems to be the overriding consideration in Canada.

\section{E. Remedies}

It is submitted that the common law remedies are unsatisfactory in that they do not fully compensate the wrongfully dismissed worker for his actual loss nor do they provide for a general right to reinstatement.

\section{Financial Compensation}

The traditional philosophies underlying the assessment of damages are, first, to put the employee in the same position as if the contract had been performed and, second, the assumption that the employer would have performed his obligations in the manner least disadvantageous to himself. This is reflected in the fundamental principle that the employee can only recover benefits to which he is contractually entitled for the period of lawful notice to terminate. ${ }^{104}$ The courts do not look beyond that date or compensate for loss suffered thereafter.

A "bonus" was held irrecoverable because it was provided on an ex

101. Mott v. Trott (1943) S.C.R. 256.

102. Unreported decision of the A.S.C., Trial Div., Macdonald J., January 1977 No. 90614.

103. Sheet Metal Components v. Plumridge, (1974) I.R.L.R. 86, 88 (N.I.R.C.); Marriot v. Oxford Co.op. (No. 2), (1969) 1 W.L.R. 254 (C.A.). Cf. Lowe v. East Lancs, Paper Mills, (1970) I.T.R. 132.

104. Laverack v. Woods of Colchester Ltd., (1967) 1 Q.B. 278 (C.A.). 
gratia basis in Floen v. Farmers and Merchant Trust Co., 105 and in Paterson v. Robin Hood Flour Mills ${ }^{106}$ certain fringe benefits were irrecoverable since there was insufficient evidence of their contractual force. A wage increase accruing during the notice period was held irrecoverable in Carey v. Drexel, ${ }^{107}$ the rationale being that the employer would not have given the plaintiff a raise had he been working out his notice period. In contrast, an increase was held recoverable in Thompson v. Norcen Energy Resources, ${ }^{108}$ but the court did not explain why. One possibility is that there is an implied contractual promise on the employer's part that he will give the plaintiff an increase similar to other workers', other things being equal, for example, job performance, departmental redundancy, etc. It is submitted that such increases should be recoverable, as with purely ex gratia bonuses.

The traditional rules were also extended, arguably unjustifiably, in Shtabsky v. Dubeta ${ }^{109}$ where an insurance salesman who quit to work for the defendant, only to be wrongfully dismissed and return to his original firm within four months of his original departure, was entitled to recover damages for the loss of clients and premiums he would have obtained had he remained with the insurance company for four months. This smacks more of the reasonable foresight test in tort! There was no evidence that the parties had expressly or impliedly contracted for such a possibility.

The Supreme Court of Canada has recently re-affirmed that deductions must be made in respect to the plaintiff's failure to mitigate loss by seeking out and taking reasonable alternative work. ${ }^{110}$ The court reemphasized that the onus of proving that the worker did not take reasonable steps is on the employer, thereby overruling the contrary view of Macdonald J.A. in John Eastbar Works v. Saskatchewan L.R.B.111 Further, the Supreme Court affirmed that monies received from other work performed during the notice period are deducted after this rule was questioned in McGuire v. Wardair Canada.112 The Alberta Supreme Court recently clarified the factors which will make an offer of other employment by the same employer unreasonable: lesser wages, status and responsibility, and the breakdown of personal relationships between the worker and management personnel with whom he has contact.113

Two recent decisions have held that unemployment insurance is not deducted from damages on the ground that the employee is entitled to benefits because he qualifies under the Unemployment Insurance Act, not because the employer breached the employment contract, i.e. insurance benefits are intended to be payable independently of legal liability flowing from a tort or breach of contract. ${ }^{114}$ These authorities are arguably inconsistent with provisions to the contrary in the Unemploy-

\footnotetext{
105. Unreported decision of the A.S.C., Trial Div., Moore J., 13th April, 1977.

106. Supra, n. 33.

107. Supra, n. 33.

108. Unreported decision of the A.S.C., Trial Div, Hope J., 21 st January, 1977.

109. (1974) 4 W.W.R. 324 (Alta. S.C., Trial Div.).

110. Red Deer College v. Michaels (1975) 5 W.W.R. 575 at 579-80 per Laskin C.J.

111. (1949) 3 D.L.R. 51 at 57 (Sask. C.A.).

112. Supra, n. 33.

113. Thiessen v. Leduc, supra, n. 33.

114. Gordies Auto Sales v. Pitre, supra, n. 34, Olson v. Motor Coach Inds. (1977) 4 W.W.R. 634 (Man. Q.B.). The issue of "collateral benefits" is beyond the scope of this paper. See Oliver, The Collateral Benefits Rule Today. in Recent Developments in Torts and Automobile Insurance. Dalhousie Continuing Legal Education Series No. 5, Halifax, 1974 (H. N. Janisch, ed.).
} 
ment Insurance Act, ss. 51-52.115 It is beyond the scope of this paper to discuss the income tax ramifications which have been thrown into doubt by the recent case of $R$. v. Atkins. ${ }^{116}$

In Alberta the traditional rules have been shaken by the decision of MacDonald J. in Abouna v. Foothills Provincial General Hospital Board.117 His Honour refused to grant a declaration and clearly considered his award of $\$ 100,000$ to be damages for wrongful dismissal. The first problem is that MacDonald J. looked beyond the notice period for the purpose of remoteness of loss. He said that since the dismissal severely injured the plaintiff's professional reputation, it would be two years before he could regain his attractiveness in the labour market. However, the plaintiff apparently had only a couple of months to run before the expiry of his fixed term contract, so that one would have expected a "cut-off" at that date. As welcome as this approach may be on policy grounds, it does not square with the authorities, which his Honour did not deal with satisfactorily. For instance, the cases he cites for remoteness of damage in wrongful dismissal do not support his approach. Armstrong v. Tyndall Quarry ${ }^{118}$ is authority that damages are recoverable only in respect to the notice period (in that case one year) and that the employee's difficulty in obtaining employment thereafter is irrelevant. Sowdon v. Mills ${ }^{119}$ was a tenancy case in which Blackburn J.'s remarks were not only obiter but also not followed in a line of subsequent cases. Chadburn v. Sinclair ${ }^{120}$ was concerned with determining the "reasonable" notice period, not with damages (indeed the court left that issue for the parties to agree on).

The second problem is that injury to reputation and loss flowing therefrom is generally not recoverable. In Peso Silver Mines v. Cropper, ${ }^{121}$ Cartwright J., delivering the unanimous judgment of the Supreme Court of Canada, said:

I agree . . . that the claim being founded on breach of contract, the damages cannot be increased by reason of the circumstances of dismissal whether in respect of the respondent's wounded feelings or the prejudicial effect upon his reputation and chances of finding other employment.

Arguably, this rule can be read as referring to the manner of dismissal as opposed to the fact of dismissal. The English House of Lords decision in Addis v. Gramophone Company $L t d .^{122}$ is generally regarded as referring to loss flowing from both the fact and manner of dismissal, but only Lord Loreburn referred to the fact of dismissal. ${ }^{23}$ The remarks in Peso might therefore be construed as relating only to manner, but MacDonald J. did not explore this possibility. In any case, Abouna's loss principally flowed from the manner of his dismissal, which bordered on defamation, rather

115. Unemployment Insurance Act [1970-71-72] (Can.), c. 48 as am. by Statutes of Canada, 1974-75-76, c. 80, s. 19. See Sublett v. Facit-Addo Canada Ltd., [1977] 2 B.L.R. 171 (Ont. H. Ct.) where unemployment insurance was deducted from the employee's damages and paid over to the Unemployment Insurance Commission. Note that 88. 51-52 refer to "remuneration". Quaere whether actions for damages for wrongful dismissal are not actions for "remuneration".

116. Supra, n. 43.

117. Supra, n. 72.

118. (1910) 16 W.L.R. 111.

119. (1861) 30 LJ.Q.B. 175 cf. Laverack, supra, n. 104; Addis, infra, n. 122.

120. Supra, n. 27.

121. (1966) 58 D.L.R. (2d) 1 at 10 (S.C.C.). Cf. Tippett v. Int'l Typographical Union (1976), 71 D.L.R. (3d) 146 (B.C.S.C.) where damages for loss of social status arising from wrongful expulsion from a trade union in breach of the membership contract were awarded.

122. (1909) A.C. 488.

123. Id. at 491. 
than from the fact of it, which would appear to make any such distinction irrelevant. His Honour also cites Dunk v. George Waller ${ }^{124}$ in which the English Court of Appeal held that apprenticeship contracts are different from normal contracts because of their educational aspects so that extra damages are recoverable for the loss of future prospects of obtaining a better job after qualification. The Court of Appeal emphasized that such contracts are "special" exceptions to the normal rule. It may be that MacDonald J. considered the "educational" aspects of surgeons' contracts as constituting a further exception, but he did not expressly say so.

A recent High Court decision suggests that English judges may be moving towards a more realistic approach. ${ }^{125}$ Lawson J. held that the emotional distress caused by the unlawful demotion of the worker (who was later dismissed) was recoverable because the parties had contemplated that loss at the date the contract was made. Although Lawson J. distinguished Addis on the ground that this breach was not a wrongful dismissal, the reasoning surely holds good where dismissal is the breach. The decision did not consider whether economic loss flowing from the emotional distress was recoverable, so that the odd situation prevails whereby the employee can recover intangible "mental" loss, but not the more identifiable financial loss in the shape of impaired employment prospects.

\section{Reinstatement}

With few exceptions, compulsory reinstatement is not available due to the courts' reluctance to apply their discretionary equitable remedies so as to specifically enforce employment contracts. ${ }^{126}$

The most important exception is that courts may grant a declaration that dismissal is void where the employee is an "office holder", or where "natural justice" standards expressly or impliedly govern dismissal by virtue of the employer exercising statutory powers, or where a statute particularizes a specific dismissal procedure.127 As seen earlier, the dismissal is a nullity, which is tantamount to reinstatement; few employers, especially in the public sector, would refuse to reinstate the employee. If the employer still wishes to discharge the worker, he must comply with the proper procedures.

The worker's application for a declaration that he remains employed does not mean that the court will grant it as of right, for the order is discretionary. If the court refuses to grant the order, ${ }^{128}$ or if the employee prefers not to be reinstated and therefore does not request it, damages lay in wrongful dismissal. The fact that the dismissal is a nullity probably does not negate the unlawful breach so as to extinguish the right to damages for wrongful dismissal. Thus, in Francis v. Municipal Councillors of Kuala Lumpur129 a clerk who was dismissed ultra vires a statutory procedure was refused a declaration that he was still employed,

124. (1970) 2 Q.B. 163.

125. Cox v. Phillips Inds. Ltd. (1975) I.R.L.R. 344 (Q.B.D.).

126. Red Deer College per Laskin C.J., supra, n. 108. Cf. Electrical Workers v. Winnipeg Builders Exchange (1967) 65 D.L.R. (2d) 242 (S.C.C.); Hill v. Parsons, (1972) 1 Ch. 305 (C.A.).

127. Supra, pp. 17-20.

128. As in Abouna, on the ground that surgeons must be a "team". See also Corporation de L'Hopital Bellechasse v. Pilotte (1975), 56 D.L.R. (3d) 702 (S.C.C.).

129. [1962] I W.L.R. 1411, esp. 1417 (P.C.). See also Vine v. N.D.L.B., [1956] 1 All E.R. 1 (C.A.) (but the House of Lords held that a declaration was appropriate, [1957] A.C. 488); Edwards v. S.O.G.A.T. [1971] Ch. 354 (C.A.); de Smith, Judicial Review of Administrative Action (Stevens, 1973, 3rd ed.) 202, 210 esp. footnote 15, and 212. Compare Earl v. Slater and Wheeler (Airlyne) Ltd. [1972] I.C.R. 508 (N.I.R.C.). See generally, Ganz, Public Law Principles Applicable to Dismissal from Employment (1967) 30 Mod. L.R. 288, esp. 300-1. 
and was granted damages for breach of his employment contract, namely his de facto wrongful dismissal. It would be unjust to allow the employer to set up his own wrongful act as a defence to the worker's claim for damages.

Where the declaration is granted, the employee is entitled to recover wages from the date of discharge up to the date of judgment, not by way of damages, but as salary owed since his employment is deemed never to have ceased. ${ }^{130}$ If there is a long delay between those dates, the worker may recover considerably more than his actual loss as the duty to mitigate is inapplicable. The reluctance of the court to see the worker "sitting in the sun" at his employer's expense may be a factor weighing against the granting of an order, the more so the longer the hiatus is; so too, if the employee has taken other employment. ${ }^{131}$

Further, the employee may be able to recover damages in the tort of "infliction of damage by the deliberate abuse of public office or authority" provided that he can prove malice or bad faith on the employer's part. ${ }^{132}$ This has not been applied in Canada in dismissal cases. Abouna may fit into this category, although the judge did not consider the possibility.

To sum up, the common law falls far short of the minimum requirements of "fairness" outlined earlier, although it is possible to detect movements in the right direction in some of the recent cases. There is an unquestionable need for statutory reform in this area. This is considered next.

\section{PROPOSALS FOR REFORM}

This part examines the extent to which, and the mechanics whereby, the "minimum contents" of a "fair" dismissal system outlined in Part I currently exist in the legislation in Nova Scotia and England, in grievance arbitration and in the proposed amendments to the Canada Labour Code. The experiences of those "just cause" systems are highly relevant in formulating unfair dismissal legislation. As will be seen, the Nova Scotia statute, which is the first of its kind in Canada, leaves unresolved many problems that have been considered more fully in arbitration and in England. Section 67(A)(1) of the Nova Scotia Labour Standards Code simply provides:

Where an employee's period of employment with an employer is ten years or more, the employer shall not discharge or suspend that employee without just cause unless that employee is ... (within the excluded categories).

The proposed amendments to the Canada Labour Code are only marginally more comprehensive than the Nova Scotia Code. Clause 61.5 provides that a person who has completed twelve "consecutive months of continuous employment" (But who is not otherwise excluded from the section) and who considers he has been unjustly dismissed can file a timely complaint with an "inspector" who, following mandatory conciliation procedures, must report to the Minister. The latter "may" refer the matter for final and binding determination by an "adjudicator" of his choice, who is empowered to grant certain remedies if he finds the dismissal was "unjust".

130. As in Mulloch, supra, n. 68 and in Vine v. N.D.L.B. (1957) A.C. 488 (H.L.)

131. See Taylor v. N.U.S., [1967] 1 W.L.R. 522; Vine v. N.D.L.B. per Singleton and Parker L.J.J. (C.A.), supra, $n$. 129; Francis per Lord Morris, supra, n. 129 at 1418.

132. de Smith, supra, n. 129 at 295-6. Quaere whether an action for the tort of breach of statutory duty is possiblesee de Smith, 473 et seq. 
In contrast, the English legislation currently contained in the Trade Union and Labour Relations Act 1974 and the Employment Protection Act 1975 is highly sophisticated and there is considerable jurisprudence in response to the problems which have arisen since its introduction in 1971. Arbitration decisions are particularly relevant in furnishing a ready-made source of "just cause" standards for a statutory scheme to tap. Although the doctrine of stare decisis is inapplicable in arbitration, general standards of "just cause" have crystallized over the years and are normally applied unless the collective agreement provides otherwise. It is therefore proposed to utilize the experiences of Nova Scotia, England, the proposed Canada Labour Code amendments, and grievance arbitration to formulate an unfair dismissal statute.

\section{A. Administration}

It is suggested that a government-financed system of tribunals should be responsible for the administration of the statute, that the tribunals be chaired by a neutral umpire with industrial relations and legal training, that the tribunals be accessible in terms of geographical location and costs (in particular, legal aid should be available to claimants), and that claims be processed speedily. Conciliation should be provided before the hearing in order to encourage voluntary settlements and should be made available to the parties at their request during the hearing. The parties should be entitled to legal representation, but proceedings should be conducted in a more informal atmosphere than that of the courts. The tribunals should not be empowered to award costs to either party, as this may discourage poorer claimants. Most frivolous claims will be weeded out in conciliation.

The Nova Scotia scheme is administered by the Labour Standards Tribunal sitting in Halifax. The extraordinarily low caseload-30 complaints were made to the Tribunal between the scheme's introduction in March 1975 and July 1977, three of which were settled prior to the hearing-does not overtax the Tribunal's bureaucracy. However, in more heavily populated provinces not operating schemes with the restrictive ten year qualifying service rule, the greater caseload would probably require an extension of existing tribunal machinery if speed and accessibility are to be assured. In England, the introduction of the legislation was marked by a vast and continuously increasing caseload in the industrial tribunals, which have original jurisdiction over twentythree employment standards statutes, including the unfair dismissal legislation. In 1965, their first year of operation, tribunals dealt with 397 cases; between February 1972 (when the unfair dismissal provisions of the Industrial Relations Act came into force) and September 1973, approximately 12,000 claims were made; and by 1976 the annual rate had risen to approximately $42,000 .{ }^{133}$ In July 1976 the average delay between the date of application and the tribunal hearing was only 10 weeks. The tribunal structure is devolved locally. The president of the tribunal system, who is appointed by the Lord Chancellor, establishes regional tribunals throughout the country (currently fourteen, including Central Offices in London, Cardiff, Glasgow and Belfast) which themselves establish tribunals for localities within their region. ${ }^{134}$ Under the Federal 
Code, applications are initially handled by the inspectorate established under section 63 to administer Part III of the Code. If the inspector cannot settle the dispute, he hands it over to the Minister who "may . . . appoint any person he considers appropriate as an adjudicator to hear and adjudicate upon the complaint." 134a The Code does not establish a permanent staff of government adjudicators. The Minister can look to ad hoc private labour arbitrators or to Labour Relations Board personnel. Clause 65.1(7)(a) seeks to guarantee speed by empowering the Governor-inCouncil to prescribe by regulation the time limit within which the adjudicator must hear the complaint.

In Nova Scotia, the procedure is for a claimant to apply to the Labour Standards Director who determines whether the dismissal is unfair. ${ }^{135}$ The employer or the employee can appeal his decision to the Labour Standards Tribunal, which consists of a chairman and two "sidesmen", with the Director representing the employee's interests in appeals by the employer. The Tribunal personnel are not legally qualified, although they are advised on legal points by Professor Christie of Dalhousie Law Faculty who is also Chairman of the Labour Relations Board. There is no provision for formal training of Tribunal personnel. In England, the Lord Chancellor appoints the chairman (often part-time) of each tribunal, who must be a lawyer of seven years' standing. Preference is given to industrial lawyers in theory, but most chairmen have little industrial relations experience. That is furnished by two "expert" local "sidesmen" who make up a 3 man tribunal (generally) and who are chosen by the Minister from a list drawn up in consultation with organizations of labour and management. The chairman selects which "experts" shall sit at which hearing, normally on a "rota" basis. Training programs are unfortunately unavailable for new members, who must "learn on the job". If labour standards tribunals are to have jurisdiction in this area, it is probable that their facilities will have to be extended in terms of geographical distribution, training programs and qualified personnel. Alternatively, jurisdiction could either lie in the labour relations boards (as currently occurs in Alberta, with the employment standards part of the Labour Act), or independent "Dismissal Tribunals" could be established for major localities manned by qualified personnel from an approved central panel who would be selected on an ad hoc or rota basis by the Minister of Labour.

The Nova Scotia, federal, and English systems are financed from public funds, unlike grievance arbitration where the parties normally share the arbitrator's costs. The latter are often exceedingly high and constitute a deterrent to smaller union locals against taking grievances to arbitration. Indeed, it is not unknown for management to try to break unions financially through excessive arbitrations. The emphasis is on informality at the tribunal hearing and the majority of claimants are not legally represented. However, in England (unlike Nova Scotia and the federal jurisdiction) if the claimant desires representation he cannot obtain legal aid, except on appeals from the tribunal's decision. This was rightly considered unjustifiable in a recent report of the English Legal Aid Advisory Committee. ${ }^{136}$ In England, costs are not awarded unless the claim is frivolous or vexatious or unless the hearing is postponed or

134a. Clause 61.5(6).

135. Labour Standards Code, s. 19.

136. 24th Report of the Lord Chancellors' Advisory Committee 1973-74. 
adjourned in certain limited circumstances. ${ }^{137}$ In contrast, costs are not awarded in grievance arbitration (unless the agreement provides otherwise) nor in proceedings before the Nova Scotia Labour Standards Tribunal, nor the "adjudicator" under the federal Code.

In Nova Scotia, the Director or his designee is obliged to inquire into all complaints and must "endeavour to effect a settlement". ${ }^{138}$ There are no data on the success rate of conciliation. The Code does not provide expressly for conciliation once Tribunal proceedings have commenced. Clause 61.5(5) of the federal Code requires an inspector to endeavour to settle the complaint for a "reasonable" time before referring the matter, upon written request of the employee, to the Minister. There is no express provision for further conciliation once the complaint is with the Minister or during the adjudication. Clause 61.5(6) gives the Minister a discretion whether to refer the complaint to adjudication, but guidelines as to the exercise of that discretion are not provided. This is potentially open to abuse. The Minister should not be given the power to "weed out" claims that he considers to be frivolous or non-meritorious. The adjudicator will take this into account in determining "just cause" in open tribunal. Nor should the Minister be empowered to determine whether the employee is qualified, for example by having the requisite "continuous employment". That is for the adjudicator to decide in open tribunal. If the discretion is intended to cover national security, $138^{a}$ that should be expressed, otherwise reference to adjudication should be mandatory.

In England, conciliation officers are required to intervene before a complaint is presented at the request of either party, ${ }^{139}$ but once proceedings have begun they can intervene at their own initiative if they consider that they could act "with a reasonable prospect of success". 140 The recent Warwick University study demonstrated that only $45 \%$ of the cases investigated reached tribunals; $28 \%$ were dropped without a settlement, often on a legal technicality; and $27 \%$ resulted in a settlement after conciliation, compared to a national rate of $25 \%$ for the same year. ${ }^{141}$ The normal settlement in conciliation is compensation, though this record may improve with the emphasis on reinstatement as the primary remedy in the 1975 amendments. Conciliation is therefore relatively successful in keeping the tribunal's caseload down.

In arbitration, there is generally no provision in collective agreements for independent conciliation in the grievance procedure and the arbitrator's function is to give a judicial determination, not to mediate. The advantages of speed, cheapness and informality traditionally attributed to arbitration have been eroded in recent years because of the high demand and fees of established arbitrators and the infusion of lawyers into the process. ${ }^{142}$ It would improve this situation considerably if the tribunal personnel were available for dismissal arbitrations on the same no-cost basis as with parties not in a collective bargaining relationship.

137. Industrial Tribunals (Labour Relations) Regulations s. 11974 No. 1386, rule 10 as am.

138. Labour Standards Code, 8. 19(1) and (2).

138a. See T.U.L.R.A. Schedule 1, para. 18.

139. T.U.L.R.A. Schedule 1, part IV, para. 26(4).

140. T.U.L.R.A. Schedule 1, part IV, para. 26(2).

141. Supra, n. 14 at 16-17.

142. See Weiler, The Labour Board and the Collective Agreement (Address to the National Academy of Arbitrators, Toronto, April 14, 1977). 


\section{B. Scope of Coverage}

It is suggested that coverage should be universal. "Face to face" employment relationships can be dealt with at the remedial stage. There should be no qualifying period of prior service. Opting out should only be permitted where alternative protection at least as favourable as the statute exists. Protection should apply to all workers in a position of economic dependency on their "employer", irrespective of the relationship not being one of master and servant stricto sensu. Exclusions are not justifiable if one takes the view that every person who relies on the provision of work by another for his livelihood and cannot guarantee "just cause" by other means should not be deprived of his living unfairly. In order to bring an action for unfair dismissal in Nova Scotia, England, and under the federal Code, an employee must, first, not fall withon one of the excluded categories and, second, have the requisite qualifying service. ${ }^{143}$

\section{Excluded Categories}

The Nova Scotia and English statutes apply only to "employees", i.e. persons working under a contract of employment, so that independent contractors are excluded notwithstanding that they may be in a position of economic "dependency" on their employer. Although clause 61.5(1) of the federal Code speaks of "persons", the fact that they must have twelve months of continuous "employment" appears to restrict protection to the "master-servant" relationship. However, clause 2 amends section $27(3)$ so that protection is available to employees exercising management functions. The Nova Scotia Code ${ }^{144}$ excludes the following employees: those "discharged" or "laid off" for any reason beyond the control of the employer, including labour disputes; those offered "reasonable alternative employment" by their employer (a hotbed of litigation!); those who have reached normal retiring age according to the "established practice" of their employer; construction workers; and employees generally excluded from the Act, notably fishermen, domestic servants in private homes, certain salesmen, agricultural workers and certain professionals whether they are practicing or students in training. The protections in the federal Code do not apply to employees who have been "laid off because of lack of work or because of the discontinuance of a function" (undefined), nor where some other statutory "procedure for redress" is available. The latter should be amended to ensure that the alternative procedural protections are at least as favourable as those under the "just cause" provisions of the Code. Otherwise, clause 61.5 applies to all employees within federal jurisdiction, including "professionals" and those exercising management functions. ${ }^{144^{\mathrm{a}}}$

In England the excluded categories are as follows: ${ }^{145}$ employees who are hired by a spouse, shore fishermen, dock-workers who are covered by

143. The complaint must also be timely. In England it must be presented within 3 months of the "effective date of termination", but tribunals are empowered to extend the period as they consider "reasonable" if they are satisfied that it was not "reasonably practical" for it to be presented in time: T.U.L.R.A. Schedule, para. 1(4). Under clause $61.5(2)$ of the federal Code, the complaint must be made within 30 days of dismissal, but this is extendable at the Minister's discretion where he is satisfied that "justice would be served". In arbitration, a more lenient approach to time limits underlies the recent amendments in the Ontario Labour Relations Act, 8. 37(5)(a), the Manitoba Labour Relations Act, s. 111.2, and the British Columbia Labour Code, s. 98(e). In England, unlike in the federal Code (clause 61.5(2)) and the Nova Scotia Code, the employee can now file a complaint before a dismissal notice expires: E.P.A. Schedule 16, part III, para. 12.

144. Section 68(3).

144a. Clause 2 of Bill C-38 will amend 8. 27(3), Canada Labour Code to that effect.

145. T.U.L.R.A. Schedule 1, para. 9, as am. by E.P.A. Schedule 16, part III; T.U.L.R.A. Schedule 1, paras. 10, 13 and 14; E.P.A. Schedule 16, part III, paras. 7 and 8. 
their own statutory scheme which gives protection against unfair dismissal, those who are employed overseas, and employees who reach normal retiring age (65 in the case of men, 60 in the case of women) except where dismissal is for an "inadmissible reason". 146 The amendments in the 1975 Act rightly removed the exclusion of firms employing less than four employees and employees of close relatives other than spouses. Interestingly, part-time employees are not excluded from the Nova Scotia Code, although the 10 year qualifying period will probably disqualify most of them. In England, part-timers who normally work less than 16 hours a week are excluded because they cannot build up the requisite 26 weeks' "continuous employment" qualifying period, though there are exceptions. ${ }^{147}$ This is considered later.

Neither the federal nor Nova Scotia Codes parallel schedule 1 paragraph 12(b) of the English Trade Union and Labour Relations Act which permits employees hired under "fixed term" contracts of two years or more to waive their right to protection. However, insofar as the expiry of any "fixed term" contract may not constitute "discharge" for the purposes of the Nova Scotia and federal Codes, the position may in fact be more disadvantageous to the employee. It is difficult to see any justification for the English contracting-out provisions except that they may permit a worker to bargain a better price for his waiver. The meaning of "fixed term" contract was considered by the Court of Appeal in B.B.C. v. Ioannu. ${ }^{148}$ Lord Denning said, "In my opinion, a 'fixed term' is one which cannot be unified by notice. To be a 'fixed term' the parties must be bound for the term stated in the agreement and unable to determine it by notice on either side." Accordingly, since the contract in question was terminable by notice, it was held not to constitute a "fixed term" for the purpose of the waiver provisions, notwithstanding that it satisfied the requirement of two years' duration. The decision has the effect of limiting the scope of the contracting-out provisions which is justifiable in light of the protective policy of the legislation. However, as will be seen, the impact of the decision on the meaning of "dismissal" potentially opened an enormous loophole in the legislation.

In England, the parties to a bilateral dismissal procedure can apply jointly to the Minister for their exclusion from the legislation under T.U.L.R.A. schedule I, paragraph 13. The minister will only approve an application if the procedure provides protection at least as adequate as that under the statute. The fact that no voluntary procedures have been approved bears out the evidence of the recent Warwick University study which suggested that the passage of unfair dismissal legislation has not encouraged the growth of voluntary bilateral dismissal procedures. ${ }^{149}$ This philosophy underlies regulation 2(5) of the Nova Scotia Regulations pursuant to the Labour Standards Code which exempts from s. 67(A)(1), "persons engaged in work as employees under a collective agreement", and clause $61.5(1)(b)$ of the federal Code which excludes employees subject to a collective agreement or employees in respect of whom an application for certification has been made. The rationale is that collective agreements contain "just cause" articles guaranteeing equal protection. This is not always the case where the union cannot win "just cause" or

146. T.U.L.R.A. Schedule; paras. $4 \cdot 6$ as am.

147. Contracts of Employment Act 1972, Schedule 1, paras. 4A and 4B.

148. (1975) I.C.R. 267.

149. Supra, n. 14 at $16 \cdot 17$. 
where "just cause" is subject to express limitations making it inferior to the legislation. It is submitted that the statute should adopt the English approach and exclude employees covered by a collective agreement only where the Minister is satisfied that the protections conferred thereunder are equally as favourable as those in the statute. This may re-adjust the balance of bargaining power, but so does all minimum standards legislation. If social justice necessitates a re-adjustment, then so be it! However, one question is whether the arbitrator or the Tribunal should have jurisdiction over "just cause" where a collective agreement is in force which does not contain equivalent protections to the statute. It may be simpler to legislate the statutory "just cause" provision into collective agreements as a "floor of rights" upon which the parties can build in collective bargaining, and allow the arbitrator to administer it. One danger, "fair representation" notwithstanding, is that grievance "bargaining" could deprive the worker of his rights. Alternatively, the worker could be given a choice of which route to take, grievance and arbitration procedures or Tribunal, but this completely ignores the union's role. In England, the organized worker is entitled to proceed in the tribunal at any time, although if he does not exhaust internal procedures first, his dismissal may not be held "unfair".149a The author's preference is that the worker be obliged to take his grievance through internal procedures, but, if the union refuses to proceed to arbitration, he should be entitled to go to the Tribunal. If a decision is made in arbitration, that should be final and binding, subject only to the normal rules for judicial review.

\section{Prior Qualifying Service}

The worst feature of the Nova Scotia legislation is the excessive 10 year qualifying period, which denies protection where it is most needed and belies the "job property" rationale propounded by the government. 150 Under the federal Code, the qualifying period is twelve "consecutive months of continuous employment". In England, the qualifying period is 26 weeks' "continuous employment" prior to the "effective date of termination" of the contract, 151 except where the reason for dismissal is an "inadmissible" one, i.e. essentially one relating the trade union membership and activities, which reflects the Act's policy of promoting the growth of collective bargaining. ${ }^{152}$ Section $1(\mathrm{nn})$ of the Nova Scotia Code defines "period of employment" as:

the period of time from the last hiring of an employee by an employer to his discharge by that employer and includes any period on lay-off or suspension of less than 12 consecutive months.

Also, section 73(3) provides that successive periods of employment with one employer shall constitute a "period" of employment except where the hiatus between two periods, during which the contractual nexus is severed, does not exceed 13 weeks. The statute therefore goes some way towards negating those technical severances of the contractual nexus which would otherwise unjustifiably destroy accrued seniority, but only for a 13 week maximum period. The federal Code does not define "continuous employment" for the purpose of the unfair dismissal

149a. Sutherland v. National Carriers [1975] I.R.L.R. 340 at 341 (I.T.).

150. Supra, n. 2.

151. T.U.L.R.A. Schedule 1, para. 10.

152. Supra, n. 146. 
amendments. Sections 29 and 30 of the Canada Labour Standards Regulations define that concept for the purposes of the maternity leave, severance pay and individual termination of employment provisions, and hopefully clause $61.5(1)(a)$ will be expressly plugged into sections 29 and 30 at a later date. Section 29 deems that absences from employment shall not rupture "continuity" where either the employer "permits or condones" the absence or where there is a "lay-off" that does not constitute a "termination" within the meaning of section 30 . The latter states that the following "lay-offs" are not "terminations" and so do not sever "continuity": those resulting from a strike/lockout; those of less than 3 months duration; those of between 3 and 6 months duration where the employer has informed the employee at or before the lay-off date that he will be recalled by a fixed date within 6 months of lay-off and the employee is in fact recalled; those in excess of 6 months duration provided that the employer continues to make payments or pension contributions during the lay-off or where the employee actually receives supplementary unemployment benefits (or is disqualified from receiving them under the Unemployment Insurance Act); and those which are mandatory under a collective agreement. In England, Schedule 1, paragraph 6 of the Contracts of Employment Act states that in respect of periods when the contract is not in force, the following situations shall not be deemed to rupture continuity: where the worker is incapable of work in consequence of sickness or injury for a maximum of 26 weeks, where he is absent from work on account of a temporary cessation of work, that is, the lay-off, where he is absent from work but the parties by arrangement or custom regard him as continuing in the job for all or any purposes, when he participates in a legal or illegal strike, and where a female employee is absent due wholly or partly to pregnancy or confinement arising therefrom up to a maximum of 27 weeks. Lastly, to protect the employee where the business is transferred (at common law his contract must end), both the Nova Scotia and English statutes deem employment to be continuous and prior seniority to count in respect of the second employer. ${ }^{153}$ Such also applies where the employee is hired by an employer which the statutes define as "associated" with his preceding employer, that is, if the employer is one over which the other company has direct or indirect control or if both are companies over which a third person has direct or indirect control. ${ }^{154}$ It is beyond the scope of this paper to examine the considerable litigation which has arisen under these provisions.

\section{The Meaning of Dismissal}

Section 1(c) of the Nova Scotia Code defines "discharge" as a "termination of employment by an employer other than lay-off". Section 1(i) defines "lay-off" as a "temporary or indefinite termination of employment because of lack of work", which is so vague that a purported "lay-off" could well turn out to be a "discharge" and therefore within s. $67 \mathrm{~A}$. For instance, does "lack of work" refer to the employee's particular job or to the overall operations of the firm? Is the test of "lack of work" the employer's subjective evaluation or the Tribunal's objective evalua-

153. Labour Standards Code, s. 10; contracts of Employment Act Schedule 1, para. 9(2). Section 45 of the Canada Labour Code includes this feature, but only for the purpose of Division III (annual vacations). It should be extended to Division V7, the unfair dismissal provisions.

154. Labour Standards Code, 8. 9; Contracts of Employment Act Schedule 1, para. 10 as am. Canada Labour Code, 8. 68.1 as am. by Bill C-8, clause 26 . 
tion? At what point is the employee justified in treating his "lay-off" as a dismissal and taking permanent employment elsewhere? These problems are not answered satisfactorily by the legislation.

In Town of Yarmouth v. Manser, the Nova Scotia Appeal Court held that "discharge" does not include termination for redundancy where the worker's job ceases to exist permanently. ${ }^{155}$ This is totally unrealistic from the worker's viewpoint. It has the horrendous effect of disentitling such workers from the severance protections in section 68 of the Code (that is, certain minimum notice periods or wages in lieu), and if applied to the "just cause" and redundancy articles in collective agreements would deprive employees of hard-won protection. It is submitted that the decision should be restricted to the context of s. 67(A)(i) pending its statutory reversal with all haste. It is, perhaps, understandable why the court decided as it did, for were "discharge" interpreted to include permanent disappearance of the job, and assuming arbitral standards are incorporated by the words "just cause", then dismissal for redundancy would not have been for "cause". ${ }^{156}$ This highly sensitive ruling was doubtlessly one which the court wished to avoid having to make! A better approach, it is submitted, is to abolish the distinction between "lay-off" and "discharge" and make all terminations by reason of "redundancy" a "dismissal". This would require a more sophisticated definition of "redundancy" than "lack of work", and one which includes disappearance of the job permanently. The English model, while not perfect, is at least a starting point. 157 The statute could then provide that dismissal for "redundancy" is fair provided the employer complies with the procedures as are outlined later. ${ }^{158}$ Under the present law, there is no restriction on the employer's freedom to "lay off" in whatsoever order he chooses! The logical progression of such amendments would be a system of redundancy compensation, which would be extremely desirable. ${ }^{159}$ The federal Code does not define "dismissal". However, it appears to give legislative effect to the Manser approach. Clause 61.5(3)(a) provides that no action may be brought by a worker who "has been laid off because of lack of work or because of the discontinuance of a function".

The Nova Scotia and federal definitions of "discharge" ignore several important situations which are covered in England viz. "constructive" dismissal, where the employer's conduct justifies the worker in resigning and treating it as a dismissal, non-renewal of fixed term contracts, "straddling" dismissals, and employee resignations before the expiry of notice to quit given by the employer.

In England, "dismissal" is defined exclusively in T.U.L.R.A. Schedule 1, paragraph 5(2):

... an employee shall be treated as dismissed if, but only if

(a) the contract under which he is employed by the employer is terminated by the employer, whether it is so terminated by notice or without notice, or

(b) where under that contract he is employed for a fixed term, that term expires without being renewed under the same contract, or

155. (1977) 72 D.L.R. (3d) 285.

156. Western Mines Led. v. Childs (1974) 51 D.L.R. (3d) 145 (B.C.S.C.); Ajack Hydro Electric Power Commission (1963) 13 L.A.C. 396 at 398-400 (Kimber). The agreement may contain express articles permitting redundancy dismissals.

157. Redundancy Payments Act 1965, c. 62, s. 1(2). See generally, Grunfeld, The Law of Redundancy (Sweet and Maxwell, 1971).

158. Infra, pp. 46-48.

159. The British. French and German systems are compared in Mukharjee. Through No Fault of Their Own (MacDonald, 1973). 
(c) the employee terminates that contract, with or without notice, in circumstances such that he is entitled to terminate it without notice by reason of the employer's conduct.

Paragraph 5(2)(a) encompasses dismissals upon full or shorter notice and summary dismissal whether or not "justifiable" at common law. It is unclear whether dismissal void $a b$ initio is included although it probably is. ${ }^{160}$ Nor is this certain in Nova Scotia or under the federal Code. It does not include termination of contract by operation of law, for example, frustration, nor genuine consensual termination. The latter has created problems in determining the "effective date of termination" under T.U.L.R.A. Schedule 1, paragraph 5(5). This is important for the purposes of determining whether the employee has the requisite period of qualifying service, which is taken from that date, and also in determining the quantum of damages for unfair dismissal. Paragraph 5(5)(a) provides that the "effective date" is the date when notice expires. Cases have arisen where the employer has given notice which, had it expired, would have qualified the employee, but the employee has allegedly "quit" during the notice period before becoming qualified. The courts have rightly held that "consensual termination" should not be inferred save in exceptional circumstances where the employee truly agreed with full knowledge of the implications it had for him. ${ }^{161}$ In the absence of agreement, the courts have held that although the "quitting" is a dismissal at common law, the contractual nexus persists until the date the original notice would have expired. ${ }^{162}$ However justifiable this is in effectuating the protective policy of the Act, it is difficult to see as a matter of common law why the "dismissal" should not effectively terminate the contract de facto or de jure at that date, unless paragraph $5(5)(a)$ is regarded as another exceptional case where the courts will order specific performance of the employment contract. ${ }^{163}$ The statute should be amended to ensure that the employee cannot be deprived of his entitlement to remedies for unfair dismissal in the "straddling dismissal" situation.

Although consensual termination does not constitute dismissal, the Act provides that where the employer has given notice to quit and the employee wishes to leave before its expiry, perhaps to take other work, he can do so and still be regarded as "dismissed" provided he gives notice of any length or form to the employer. ${ }^{164}$

Constructive dismissal is covered by $5(2)(\mathrm{c})$. Where the employee genuinely consents to a unilateral variation, there is no dismissal. The earlier decisions construed this section as requiring that the employer's conduct constitute a repudiation of the contract, but recent cases have moved away from the contractual analysis in order to accommodate the realities of industrial life, recognizing that the employer can effectively drive the worker from the job without repudiating the contract. Thus, in George Wimpey v. Cooper, Phillips J. said:165

For example, if an employee relies on the conduct of the employer as entitling him to terminate the contract of employment, such conduct, we think, may properly fall within paragraph $5(2)(c)$ notwithstanding that it is not expressly in breach of contract, if it is of

160. Supra, n. 129 and accompanying text.

161. McAlwane v. Boughton Estates (1973) 2 All E.R. 299 (N.I.R.C.).

162. Lees v. Arthur Graves, (1974) I.C.R. 501 (C.A.); Smith v. Brindle, [1973] 1 All E.R. 230 (C.A.).

163. Hill v. Parsons, [1972] 1 Ch. 305 (C.A.). As to the argument whether wrongful dismissal gives rise to automatic termination, see Freedland, supra, n. 21 at 292-300.

164. T.U.L.R.A. Schedule 1, para. 5(3) as am.

165. (1977) I.R.L.R. 205, at 206 (E.A.T.); Turner v. London Thansport Executive [1977] I.R.L.R. 441, at 445 per Megaw L.J. (C.A.); cf. Wetherall v. Lynn [1977] I.R.L.R. 333 (E.A.T.). 
a kind which in accordance with good industrial practice, no employee could reasonably be expected to accept.

However, in the latest decision on point, the Court of Appeal has unfortunately reverted to the view that the employer's conduct must constitute a repudiation of the contract. .65a $^{\mathrm{a}}$ The non-renewal of fixed term contracts is deemed a "dismissal" by paragraph $5(2)(\mathrm{b})$, otherwise the employer could drive a coach and four through the Act by imposing short-term fixed contracts on his workers. However, the Court of Appeal decision in B.B.C. v. Ioannu ${ }^{166}$ opened a loophole in this section by defining "fixed term" contracts as those not providing for express notice of termination prior to expiry of the term. If the contract did include such a provision, it fell outside paragraph $5(2)(b)$, unless the employer terminated under the notice clause. The consequence was doubtlessly unforeseen by the court who were concerned with avoiding the unjust results of the "waiver" exclusion. In L. D. Dixonv. B.B.C. et al., 166a the E.A.T. avoided this problem by restricting the Ioannu definition of "fixed term" to the context of that case, namely the "waiver" provisions under T.U.L.R.A. Schedule 1, paragraph 12(b), so that the expiry of such contracts would constitute "dismissal" within the different context of paragraph $5(2)(b)$. The preferable solution is to abolish the "waiver" provisions and define "fixed term" as a specified period irrespective of provision for prior termination. The burden of proving a "dismissal" and the "effective date of termination" is on the employee.

It is suggested that statutory definitions of "dismissal" should parallel the more sophisticated English model, with the additions suggested above, rather than leave so many questions open as do the Nova Scotia and federal Codes.

\section{Standards of Fairness}

It is suggested that unfair dismissal legislation should contain the following elements of "fairness".

1. Guidelines for the tribunal and industry as to "fair" standards should be publicized in a government Code of Practice. A "roving inspectorate" should be established with powers to examine existing dismissal procedures and to recommend reforms. "Unfair" dismissals in breach of such recommended reforms should result in double compensation for the worker and the denial of government contracts to the firm in question.

2. The tribunal should have a broad discretion to determine "fairness" subject to the following, which should be stated in the Code of Practice:

(a) Certain grounds should be automatically unfair in addition to those currently prohibited in human rights and labour legislation, notably sexual orientation, familial relationship and political opinion. Redundancy should only be a "fair" reason for dismissal if a "reasonable" employer would have cut back on labour in the circumstances of the case, and if the employer gives reasonable notice, attempts to avoid redundancy by other means, tries to find the worker other employment in his or associated firms, allows time off to find other work, and selects 
those to be made redundant in accordance with a bilaterally formulated procedure, which may be "last in-first out". In addition, statutory compensation for "fair" redundancy dismissals should be introduced.

(b) The dismissal procedure must be formulated and administered bilaterally and provide for "progressive discipline", notice of the alleged offence, right to state a case, right of appeal to a body above the original decision-making body, maintenance of the "status quo" pending final determination, and the onus of proving "fairness" should be on the employer.

(c) The work rules and penalties for breach thereof should be formulated bilaterally and publicized, they should be applied consistently and non-discriminatorily, any changes therein or new rules should be publicized and a reasonable period for readjustment allowed, dismissal should be "unfair" where the employer raises new offences so as to "surprise" the worker, employer condonation of previous offences should preclude their being utilized to discharge a worker subsequently, even in combination with a fresh offence committed by the worker, the severity of the penalty must be related to the nature of the offence and the offender so that mitigating circumstances are taken into account, a minimum one year "wipe the slate clean" provision should apply universally, and the tribunal should be allowed to question the employer's business decisions by reference to the "reasonable" employer. The extent to which these elements exist in Nova Scotia, England and in arbitration is considered below.

\section{A Code of Practice}

Neither the federal nor the Nova Scotia government has published a Code of Practice for the guidance of the adjudicator and those in industry. Given the "corrective" philosophy of industrial discipline and the need to educate and reform bad industrial practice, this is a serious omission. In England, an Industrial Relations Code of Practice was published in 1971 as a guideline for the operation of industrial relations in general. Articles 130-133 of the Code, which dealt with disciplinary procedures, were replaced in 1977 by a new Code of Practice on Disciplinary Practice and Procedures in Employment. The Code has no legal effect of itself, though it may be taken into account in other legal proceedings where ". . . it appears to the tribunal to be relevant". ${ }^{167}$ Tribunals have taken account of the "spirit" of the Code as paragraph 6(8) "circumstance". Violation of its letter does not automatically render a dismissal unfair; rather, the Code's significance varies according to the circumstances of each case. There is no provision for a "roving inspectorate" with the functions outlined above.

\section{The General Test}

Section $67(A)(1)$ of the Nova Scotia Code merely states that dismissal must be for "just cause". The federal Code simply refers to "unjust dismissal". Presumably arbitration rather than common law standards are intended to apply, otherwise there would be little need for the sections. 
However, it is unclear to what extent the standards will be followed. The leading work on arbitration defines "just cause" as follows:168

The employer must affirmatively establish that as a result of some misconduct or disability, the grievor has demonstrated his incompatibility with the continuation of the employment relationship or has seriously prejudiced or injured the reputation or some other legitimate interest of the employer.

Although the doctrine of stare decisis is inapplicable in arbitration, certain commonly accepted standards have evolved which provide the parties with reasonably predictable guidelines. Once the grievor has established the "basic ingredients" namely "employee" status, existence of a "just cause" article, and dismissal, the onus shifts to the employer to prove "just cause", 169 and where incompetence is the alleged reason for dismissal, the established standards of efficiency applying to the job. ${ }^{170}$ Once the employer has shown prima facie grounds for "just cause", the employee must raise any defences or mitigating circumstances. Most arbitrators apply the usual civil law standard of proof which requires that the emplyer prove his case "on a balance of probabilities",171 whereas some apply a stricter standard especially where serious misconduct is involved. Thus allegations of criminal misconduct have been held to require substantiation by "clear evidence" or "reasonable probability".172

In England, once the employee has proved "dismissal", the onus shifts to the employer to establish that the principal reason for dismissal relates to one or more of the following: ${ }^{173}$ the "capability or qualifications" of the employee in respect to "work of the kind" he was hired to perform, the employee's "conduct", redundancy, an enactment which makes continued employment unlawful, or "some other substantial reason of a kind to justify" dismissal. Failure to discharge this burden automatically results in an unfair dismissal.

If the employer discharges the initial onus, he must then jump a second hurdle. Paragraph 6(8) provides:

Subject to subparagraphs (4) to (7) above, the determination of the question of whether the dismissal was fair or unfair, having regard to the reason shown by the employer, shall depend on whether the employer can satisfy the tribunal that in the circumstances (having regard to equity and the substantial merits of the case) he acted reasonably in treating it as a sufficient reason for dismissing the employee.

Significantly, the burden of proof is on the employer.

Subparagraphs (4)-(6) provide that dismissal for "inadmissible" reasons (basically union activities and rights to union membership) is automatically unfair except in certain closed shop situations. Subparagraph (7) provides that dismissal for redundancy is automatically unfair where the redundancy situation applies equally to one or more employees holding a "similar" position as the claimant and the principal reason for selecting the claimant is either an "inadmissible" one or his selection contravenes a "customary arrangement or agreed procedure relating to redundancy", 174 save where "special" reasons justify such contravention. If the federal and Nova Scotia Codes incorporate

168. Brown and Beatty, supra, n. 11 at 291.

169. Baton Broadcasting (1970) 21 L.A.C. 7 (O'shea).

170. Re Gov't of Sask. and Sask. Gov't Employees Assoc. (1976) 11 L.A.C. (2d) 244 (Barclay).

171. Toronto East General Hospital Inc. (1975) 9 L.A.C. (2d) 311 (Beatty).

172. Ford Motor Co. of Canada (1975) 8 L.A.C. (2d) 188 (Ferguson)

173. T.U.L.R.A. Schedule 1, para. 6.

174. "Last in-first out" is not a "customary arrangement" unless the parties have adopted it in the past. Bessenden Props. v. Corness (1974) I.R.L.R. 388 at 340 per Roskill L.J. (C.A.). 
arbitration standards, the interesting result would be that dismissal for redundancy is not "just cause".175 It was, perhaps, to avoid making that decision that the Appellate Division ruled as it did in the Manser case. Even when dismissal is prima facie "fair" under paragraphs (4)-(7), the tribunals have held that the employer must then proceed to establish "fairness" under the general test in paragraph 6(8). ${ }^{176}$ However, if dismissal is unfair as in breach of subparagraphs (4)-(7), that is an end to the matter and paragraph $6(8)$ is irrelevant.

In addition, dismissal is automatically unfair if the principal reason is that the employee is pregnant, or for reasons connected with her pregnancy, or where she is refused reinstatement after pregnancy. 177 The same applies where the employee has a "spent" conviction under the Rehabilitation of Offenders Act 1974 s. 4(3). As with arbitration, stare decisis is inapplicable to tribunals so that ultimately each case rests on its facts.

\section{Procedural Fairness}

The English Code of Disciplinary Practice and Procedure recommends the following procedural standards:

(i) Article 5 recognizes the right of employees to participate in the initial formulation and subsequent amendment of procedures, although it places the responsibility for initiating a "fair" procedure on management. In arbitration, the structure of the internal grievance procedure is a negotiable item so that worker involvement is assured at the bargaining table. The federal and Nova Scotia Codes should follow the English approach since there is no guarantee that non-organized workers can win a voice in formulating procedures.

(ii) The English Code incorporates certain "natural justice" standards. Article 10 lays down the following "essential features":

10. Disciplinary procedures should:
(a) Be in writing.
(b) Specify to whom they apply.
(c) Provide for matters to be dealt with quickly.
(d) Indicate the disciplinary actions which may be taken.
(e) Specify the levels of management which have the authority to take the various forms of disciplinary action, ensuring that immediate superiors do not normally have the power to dismiss without reference to senior management.
(f) Provide for individuals to be informed of the complaints against them and be given an opportunity to state their case before decisions are reached.
(g) Give individuals the right to be accompanied by a trade union representative or by a fellow employee of their choice ... .
(i) Ensure that disciplinary action is not taken until the case has been carefully investigated.
(j) Ensure that individuals are given an explanation for any penalty imposed.
(k) Provide a right of appeal and specify the procedure to be followed.

It seems implicit in $10(e)$ and ( $f$ ) that appeals need only be made to higher management. As stated earlier, it is more desirable that appeals be made to a joint worker/management committee as occurs in arbitration where grievances are "bargained" internally. In addition, article 13 provides

175. Supra, n. 156 and accompanying text.

176. Vokes v. Bear (1974) I.C.R. 1 (N.I.R.C.).

177. E.P.A., 8. 34(1). See also Canada Labour Code, s. 59.4; Nova Scotia Labour Standards Code, s. 56(1). Clause 20 of the federal Bill proposes to make dismissal for pregnancy unfair irrespective of the worker's length of service. 
that written details of disciplinary action, except for oral warnings, should be given to the employee along with an explanation of available appeal procedures.

If dismissal is invoked, the worker should know the reasons why, not only for evidentiary purposes in determining the employer's motive at the tribunal, but also because it is inherently "fair". Section 70 of the Employment Protection Act requires employers to provide qualified employees upon request with written particulars of the reason(s) for discharge within 14 days of such request. If the tribunal finds that the employer either refused the request or provided an "inadequate or untrue" record, it can make a declaration as to its findings on the reasons and award the employee two weeks' wages. Clause 61.5(4) of the federal Code requires employers to furnish written reasons for dismissal within 15 days of a written request by the worker to the inspector.

(iii) It is recognized as unfair in England and in arbitration that the employer be permitted to justify dismissal on grounds which either came to his knowledge or occurred after the date of dismissal, thus reversing the common law rule in Boston Deep Sea Fisheries and Icing v. Ansell.178 This avoids "taking the employee by surprise", and in the context of arbitration, affirms the role of the grievance procedure by ensuring that the new grounds are grieved before arbitration. In England, it appears that subsequent conduct of the same type that attracted dismissal can be taken into account as corroborative evidence of the employer's motive for dismissal, but cannot of itself constitute a justifiable reason for dismissal since paragraph 6(8) requires the reason to exist before or at the date of dismissal. ${ }^{179}$ In arbitration, however, new grounds for dismissal based on identical facts necessary to support the original ground are technically admissible as independent reasons for dismissal, ${ }^{180}$ though in practice the difference may be unimportant. The wording of paragraph 6(8) seems to preclude English tribunals from adopting two arbitration practices. First, arbitrators permit discharge to be on non-expressed grounds provided that those grounds are implicitly encompassed within the expressed grounds so that the employee reasonably knows that those grounds are in effect being relied on..$^{181}$ Strictly speaking, if the non-expressed grounds occurred or became known to the employer after the date of dismissal, they must be discounted as separate reasons (but not as corroborative evidence) in England. This also applies to the second arbitration practice, whereby the employer is allowed to base dismissal on new grounds which he did not, or could not reasonably have been expected to know at the date of dismissal, provided that the parties either have had sufficient time to consider the new grounds in the grievance procedure or have had enough time to prepare the issue before arbitration. ${ }^{182}$ It is suggested that the extra flexibility of the arbitration approach should be incorporated into unfair dismissal legislation, though the tribunal must proceed with extreme caution lest the Ansell rule is resurrected. Lastly, conduct inadmissible as grounds justifying discharge is taken into account in England and in arbitration at the remedial stage in determining the separate issue of appropriate remedies. ${ }^{183}$

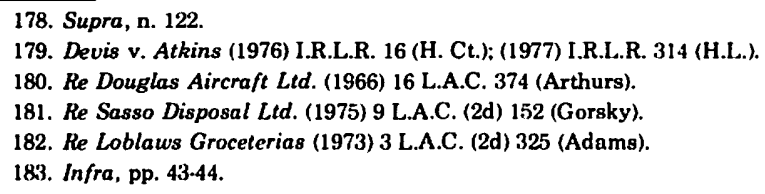


(iv) It is important that the content of rules are publicized to employees so they know the standards required of them. Article 6 of the English Code recommends that disciplinary rules be as certain as possible, given that no set of rules can cover all circumstances that may arise. Article 7 imposes upon management the responsibility for ensuring that employees know and understand the rules, which:

.. . may be best achieved by giving every employee a copy of the rules and by explaining them orally. In the case of new employees this should form part of an induction program.

Article 8 requires that employees be made aware of the consequences of violating the rules, and in particular which misconduct will result in dismissal. Article 20 provides that procedures should be reviewed periodically to take account of prevailing conditions and that any:

amendments and additional rules imposing new obligations should be introduced only after reasonable notice has been given to all employees and, where appropriate, their representatives have been informed.

This position is similar to arbitration where management introduces novel rules pursuant to its "management rights". Before dismissal is justified, such rules must be unequivocal, brought to the employees' attention, and have been consistently enforced by the employer from the time introduced.184 Further, recent cases suggest that the rules must be reasonable in content, non-arbitrary and introduced in good faith, ${ }^{185}$ a welcome step forward.

(v) Both the English and arbitration ${ }^{186}$ models adopt a "corrective" philosophy of industrial discipline. It follows from this philosophy that disciplinary sanctions should be applied in a "progressive" fashion. Thus article 10 of the English Code states that procedures should be designed ". . . to emphasize and encourage improvements in individual conduct", and article 12 recommends the following "progressive" steps:

(a) In the case of minor offences the individual should be given a formal oral warning or if the issue is more serious, there should be a written warning setting out the nature of the offence and the likely consequences of further offences. In either case the individual should be advised that the warning constitutes the first formal stage of the procedure.

(b) Further misconduct might warrant a final written warning which should contain a statement that any recurrence would lead to suspension or dismissal or some other penalty, as the case may be.

(c) The final step might be disciplinary transfer, or disciplinary suspension without pay (but only if these are allowed for by an express or implied condition of the contract of employment), or dismissal, according to the nature of the misconduct. Special consideration should be given before imposing disciplinary suspension without pay and it should not normally be for a prolonged period.

This is substantially the same as arbitral practice. Where dismissal is for misconduct, "progressive" measures are only dispensed with where misconduct is "gross", 187 and perhaps where senior management are involved. ${ }^{188}$ One decision has suggested that warnings can be dispensed

184. Re K.V.P. Ltd. (1975) 16 L.A.C. 73 (Robinson); Winnipeg Teachers Assoc. v. Winnipeg School Division No. 1, 77 C.L.L.C. 14067, at $15380-81$ per Laskin CJ. (S.C.C.)

185. I.N.C.O. v. U.S.W. (1977) 14 L.A.C. (2d) 13 (Shime).

186. Re Galco Food Products (1974) 7 L.A.C. (2d) 350 (Beatty).

187. U.K. Code of Practice as Disciplinary Practice and Procedures in Employment, article 10(L); C. H. Cates and Sons Ltd. (1974) 7 L.A.C. (2d) 121 (Monroe).

188. Atkin v. Enfield Group Hospt. Manag. Committee, (1974) I.R.L.R. 45 (N.I.R.C.); Clarkson Int'l Tool v. Short. (1973) I.C.R. 191 (N.I.R.C.). 
with where the misconduct is "not in the interests of the business", 189 but it is suggested that this is too wide.

Although these articles are headed "disciplinary procedures", their spirit is applied in capability dismissals. As is the case in arbitration (at least for non-probationers), where dismissal is for incompetency, explicit warnings are generally required as a prerequisite to dismissal. As Griffiths said in Winterhalter Gastronom v. Webb:190

There are many situations in which a man's apparent capabilities may be stretched when he knows what is demanded of him; many do not know they are capable of jumping the five barrelled gate until the bull is close behind them.

Although some decisions suggest that a warning and opportunity to state the case must always precede a "fair" dismissal, 191 the consensus is that these can be dispensed with where it is manifest from the employee's "irredeemable" incompetence that he will not improve or where senior management, who by the nature of their jobs know the standards required of them, are involved. ${ }^{192}$ However, these exceptions must be applied cautiously, as Phillips J. said in Mansfield Hosiery Ltd. v. Bromley: 193

However, cases of that kind need to be regarded with some care because it is a very slippery slope and it is not the wish of the E.A.T. to lessen the need for proper procedure by encouraging industrial tribunals to say: 'Well, it would not have made any difference in the end', except in very clear cases.

A corollary of the "corrective" philosophy is that mitigating circumstances must be taken into account, that is, the seriousness of the penalty must be tailored to the circumstances of the offence and the offender. Following is an often cited "check-list" formulated by arbitrator Reville ${ }^{194}$ which, although concerned with the arbitrators' exercise of the power to substitute penalties at the remedial stage, is also followed in the initial determination of "cause".

1. The previous good record of the employee.

2. The length of service of the employee.

3. Whether or not the offence was an isolated incident in the employee's working history.

4. Provocation by management.

5. Whether the infraction was pre-meditated or whether it occurred on the spur of the moment as a momentary aberration due to strong emotional impulses.

6. Whether the penalty imposed was or created a special economic hardship for the employee in the circumstances of his case.

7. Whether the employer has not enforced uniformly the rule in question so that there is an element of discrimination.

8. Circumstances negating intent, e.g. that the employee misunderstood the nature of the order.

9. The seriousness of the offence in terms of company policy and obligations.

189. James v. Walcham U.D.C. (1973) I.C.R. 398 (N.I.R.C.).

190. (1973) I.R.L.R. 120 at 122 (N.I.R.C.).

191. Jamieson v. Aberdeen County Council, (1975) I.R.L.R. 348 at 350 (Ct. Sess.).

192. Dunning v. Jacomb (1973) I.C.R. 448 (N.I.R.C.); James v. Waltham U.D.C. (1973) I.C.R. 398 (N.I.R.C.); Re Ryerson Polytechnical Institute (1976) 12 L.A.C. (2d) 58 (Simmons).

193. (1977) I.R.L.R. 301 (E.A.T.).

194. Steel Equipment Case (1964) 14 L.A.C. 356. 
10. Other mitigating factors, such failure to allow the employee to state his case, or personal problems affecting the employee, and other exacerbating factors, e.g. failure of the employee to attempt to settle the matter upon having being given the opportunity to do so, or the employee's attempt to lie his way out of the matter.

These factors are generally applied as paragraph 6(8) "circumstances" under the English legislation. ${ }^{195}$

Another corollary of "progressive" discipline is that provision should be made for periodically removing past infractions from the employee's record, that is, "wiping the slate clean". This is envisaged in article 19 of the English Code which provides:

Except in agreed special circumstances breach of disciplinary rules should be disregarded after a special period of satisfactory conduct.

In arbitration, the "culminating incident" doctrine protects the employee against "double penalties", but only to a very limited extent. ${ }^{196}$ Under this doctrine, the arbitrator is only permitted to rely on infractions previously committed by the employee in deciding whether dismissal is for cause if the dismissal is based on a new infraction. In that case, the new infraction constituting the reason for the dismissal "triggers" the employee's prior work record which then can be used in determining whether, in view of the totality of the employee's conduct, dismissal is warranted. The rationale of the doctrine is that to allow management to dismiss exclusively on the basis of past infractions which have already been the subject of disciplinary action, or which may simply have been ignored, would constitute a "double penalty". Not every new offence will suffice to "trigger" the employee's past record. Thus, in one case where the employee struck a management person, the arbitrator held that mitigating circumstances (the employee was distraught due to family problems of which the management person was aware and the latter was unreasonably "harrassing" the employee) made the offence insufficiently serious to warrant the "triggering" of the employee's poor work record so that dismissal was not warranted. ${ }^{197}$ Similarly, not every aspect of the grievor's past work record is admissible pursuant to the "culminating incident". Infractions which were not disciplined or put on the employee's "work record" are disregarded because the employee is entitled to feel that such offences are tolerable as being "part of the normal give and take of the work place".198 A recent arbitration decision suggests that such "ignored" infractions may be taken into account in exceptional circumstances where the grievance process is so unstructured as to be unknown to the employee, so that, absent discipline, he will be misled by the employer's assessment of his conduct, or where there is no dispute about the factual nature of what the employee had done.199 These exceptions rest on the assumption that there is no reason to believe that the employee thought his conduct was within the limits of what is tolerable in the plant. Further, prior "recorded" infractions will not be given great weight if they are not of the same nature as the offence

195. Code of Practice on Disciplinary Practices and Procedures in Employment, article 14.

196. See Re Weston Bakeries (1974) 5 L.A.C. (2d) 38 (Adell).

197. Re Ford Canada Ltd. and U.A.W. Local 707 (1974) 7 L.A.C. (2d) 199 (Palmer).

198. Re SKF Man. of Canada and Int'l Assoc. of Machinists Local 901 (1975) 9 L.A.C. (2d) 138 (Shime); Canada Starch Col. Ltd. (1972) 1 L.A.C. (2d) 122 (Simmons); Re Hawker Siddeley Canada (1977) 13 L.A.C. (2d) I (Richard).

199. Re Canadian Luckens Ltd. and U.S.W. (1976) 12 L.A.C. (2d) 439 (Schiff). 
constituting the "culminating incident", or if they are of a non-serious nature. ${ }^{200}$ If the employee failed to grieve the imposition of a previous sanction he is permitted to submit an explanation at the subsequent hearing in relation to the culminating incident. ${ }^{201}$ From the employer's viewpoint, the "culminating incident" doctrine is normally justified as accommodating the principle of the "straw that broke the camel's back". The doctrine may be criticized on the ground that it can result in an unfair "double jeopardy" for the employee in that his dismissal may be based partially on previously disciplined offences. Exceptionally, some arbitrators have been prepared to countenance a limited inherent "wipe the slate clean" provision in the absence of express provisions in the agreement. In 1967, ${ }^{201 a}$ Professor Arthurs held that previous warnings to an employee in respect of absenteeism and lateness had become "spent" after an unspecified period of punctuality by the employee, so that they could not be "triggered" by an offence of a different nature, though they could be by an offence of the same nature. In a 1975 award, ${ }^{201 b}$ arbitrator Abbott intimated that he may have treated earlier offences as "spent" after a period of improvement had the "culminating" incident not been of the same nature. It is submitted that Canadian unfair dismissal legislation should not incorporate the culminatory incident doctrine; rather, the English model should be extended to provide for a minimum one year "wipe the slate clean" provision.

(vi) It was suggested earlier that "fairness" should include the maintenance of the "status quo" in the sense that dismissal should not be implemented until its justification is established. If the worker's removal from the job is necessary as a "protective" measure, it should be with full pay.202 This principle is not applied in arbitration. The consensus of arbitral opinion is that employees must perform a disputed work assignment and test its validity later in the grievance procedure, the rationale being that uninterrupted production is part of the benefit employers can legitimately expect from the grievance procedure. ${ }^{203}$ The employee is not justified in disobeying an order simply because there is reasonable doubt about the proper interpretation of the collective agreement. It is well established that an employee is justified in refusing an assignment if he bona fide and reasonably believes the work to be illegal, unsafe, or beyond his physical capacity, even if his belief is unfounded in fact. Arbitrators are careful to limit the exceptions to the general rule, although in one case, Professor Weiler held that a union official was justified in disobeying an order to stay on the job in order to attend a grievance hearing at which his presence was essential. ${ }^{204}$ Presumably a non-negligent mistake of fact or the impossibility of carrying out the assignment would also justify non-performance.

The English Employment Protection Act ss. 78-80 introduces a limited "status quo" requirement into the unfair dismissal legislation. If an employee alleges as the reason for dismissal, his participation in union activities or his desire to acquire union membership, he can apply to the tribunal within 7 days for an "interim" order either that he be reinstated,

200. Re SKF, supra, n. 198.

201. SKD Man. Ltd. (1969) 20 L.A.C. 231 (Weiler).

201a. U.A.W. and Douglas Aircraft Ltd. (1967) 18 L.A.C. 27 (Arthurs).

201b. Steel Co. of Canada (1975) 8 L.A.C. (2d) 213 at 218 (Abbott).

202. Supra, p. 4.

203. For example, see Re Seneca College (1976) 12 L.A.C. (2d) 27 (Weatherill).

204. Stancor Central Ltd. (1970) 22 L.A.C. 184 (Weiler). 
or re-engaged in another job mutually acceptable to himself and his employer. If the employer rejects both alternatives, the tribunal can order that he be suspended at full pay. However, these remedies are only available if the tribunal considers the employee as "likely" to suceed at the final hearing. Further, the procedure only applies to dismissal for "inadmissible reasons", which furthers the Act's objective of promoting collective bargaining. If one accepts that individual interests are as important as those of the collectivity, the principle should be of general application in unfair dismissal legislation.

(vii) Dismissal for redundancy is not "just cause" in arbitration. ${ }^{205}$ It is consistent with I.L.O. Recommendation \#119 that such dismissals be regarded as "fair" provided that certain procedural safeguards exist. In England, redundancy dismissals which satisfy the paragraph 6(7) criteria of "fairness" may still be held "unfair" under paragraph 6(8). Articles 45 and 46 of the Code of Practice 1971 are taken into account as a paragraph 6(8) "circumstance":

45. A policy for dealing with reductions in the work force, if they become necessary, should be worked out in advance so far as practicable and should form part of the undertaking's employment policies. As far as is consistent with operational efficiency and the success of the undertaking, management should, in consultation with employee representatives, seek to avoid redundancies by such means as:

(i) restrictions on recruitment;

(ii) retirement of employees who are beyond the normal retiring age;

(iii) reductions in overtime;

(iv) short-time working to cover temporary fluctuations in manpower needs;

(v) re-training or transfer to other work.

46. If redundancy becomes necessary, management in consultation, as appropriate, with employees or their representatives, should:

(i) give as much warning as practicable to the employees concerned and to the Department of Employment;

(ii) consider introducing schemes for voluntary redundancy, retirement, transfer to other establishments within the undertaking, and a phased rundown of employment;

(iii) establish which employees are to be made redundant and the order of discharge;

(iv) offer help to employees in finding other work in co-operation, where appropriate, with the Department of Employment, and allow them reasonable time off for the purpose;

(v) decide how and when to make the facts public, ensuring that no announcement is made before the employees and their representatives and trade unions have been informed.

The spirit of those articles underlies section 99 of the Employment Protection Act which obliges employers to consult with recognized trade unions, but not with employees in non-union forms, in advance of certian redundancies. Thus, dismissal without consultation is almost always unfair in union plants. ${ }^{206}$ In non-union plants redundancy dismissals may be held unfair where the employer fails to consult employees in advance, fails to operate bilateral selection procedures, fails to give reasons for his selection for discharge, fails to assist the employee in finding other work either in that or an associated company, or fails to allow the employee time off to find employment elsewhere. ${ }^{207}$ These

205. Supra, n. 156.

206. North East Midlands Co-op v. Allen (1977) I.R.L.R. 212 (E.A.T.); see Freedland, Employment Protection: Redundancy Procedures and the E.E.C., (1976) 5 I.L.J. 24.

207. Vokes v. Bear, supra, n. 176; Rigby v. B.S.C. (1973) I.T.R. 191 (N.I.R.C.); Norton v. Chemidus Wavin (1975) I.R.L.R. 294 (I.T.) 
features should be included in Canadian legislation regulating the "fairness" of redundancy dismissals.

\section{Substantive Fairness}

The English legislation provides procedural safeguards for the exercise of management's dismissal power, but it does not question the content of managerial policy decisions. Tribunals do not say that a redundancy is "unfair" because the shareholders ought to take cuts in dividends; rather, they attempt to "cushion" the blow and sweeten the pill of redundancy. Nor do they say that management should not increase the speed of the line; rather, they require that employees be given reasonable time to readjust. In that sense therefore, some would argue that the legislation does not protect against "unfair" dismissal. Similarly, the arbitrator's jurisdiction does not extend to striking down management policy decisions because he thinks them "unreasonable" unless the agreement expressly allows him to do so. The arbitrator can only require that the rules be implemented fairly and in good faith, although one recent decision suggests that new rules created by management can be reviewed by the arbitrator on the "reasonableness" of their content.208 It is submitted that this is too narrow a perspective of "fairness" and that the tribunals should be empowered to question managerial policy decisions that result in dismissal by the standards of the "reasonable employer".

\section{E. Remedies}

The primary remedy should be reinstatement or re-engagement on terms at least as favourable. Compensation should be a "last resort" remedy where reinstatement is clearly impracticable, as in "face to face" industries where interpersonal relationships have clearly been irretrievably destroyed on the facts, where the employee wishes to leave, or where the job has disappeared by reason of redundancy. Compensation should not be restricted, as at common law, to a contract notice period. It should represent the worker's actual loss, including personal anguish and economic loss flowing therefrom, loss of accrued seniority and redundancy benefits, anticipated loss of reasonably-expected benefits beyond the notice period and no deductions in respect of unemployment benefits should be made. Damages should be taxed in the worker's hand; tax should not be deducted from wages before the worker receives them as damages. The tribunal should be empowered to substitute the employer's penalty, order reinstatement without back pay and impose unpaid suspensions in order to take account of contributory "blameworthiness" on the employee's part. Where exclusively compensation is awarded, no reduction on account of such "blameworthiness" should be made in excess of $80 \%$ of total compensation at the most.

\section{Reinstatement and Re-Engagement}

In England prior to the 1975 amendments, the law was unsuccessful in securing reinstatement and re-engagement of unfairly dismissed employees, partially because the tribunals had no mandatory powers, and partially because of the tribunals' reluctance to exercise their recommendatory powers. ${ }^{209}$ Thus, in $197413.4 \%$ of claims were successful in the tribunals but in only $0.6 \%$ were recommendations made. By contrast, four times as many reinstatements and re-engagements were achieved in con- 
ciliation. ${ }^{210}$ Accordingly, the 1975 amendments place a compelling onus on tribunals to order reinstatement, which is clearly envisaged as the primary remedy. Section 71(7) obliges the tribunals to consider making an order of reinstatement first. Only if such an order is not made may the tribunal consider re-engagement. Compensation cannot be awarded unless and until the tribunal decides not to order either reinstatement or re-engagement. ${ }^{211}$

In exercising their discretion to order reinstatement, the tribunal must take account of the wishes of the employee after having explained the nature of the order to him, whether it is "practicable" for the employer to comply, and whether the employee was partially at fault for the dismissal.212 In determining "practicability", no account is taken of replacements hired by the employer unless he proves either that it was "impracticable" to have replacements on a temporary rather than a permanent basis or that the employee delayed for an "unreasonable" time in notifying him of his desire to be reinstated in circumstances when it was no longer "reasonable" to hire a temporary replacement. ${ }^{213}$ Under the old "reasonably practicable" test, employers could normally defeat a reinstatement recommendation by hiring permanent replacements irrespective of temporary ones being available. There is no justification for denying reinstatement on the ground of partial employee "fault". If the dismissal is technically unfair, the worker should have the right to regain his job! Significantly, the reinstated employee is treated as if he had never left so that he is entitled to all benefits he would have obtained during the hiatus, except that deductions are made for wages earned elsewhere, ex gratia benefits (e.g. social security), wages in lieu of notice received and "such other benefits as the tribunal thinks appropriate in the circumstances". ${ }^{214}$ Unlike in arbitration, no reduction can be made for contributory "blameworthiness". The philosophy is avowedly compensatory, although the employee does not acquire additional monies for the inconvenience and upset of an unlawful interference with his rights! Nor is the employer punished; in fact, he may benefit from the specified deductions!

Re-engagement is an order that the worker be re-hired under a fresh contract with either the original, successor or associated employer in a job which is either "comparable" to his old one or otherwise "suitable".215 The relevant factors governing the tribunal's discretion and the deductions made are the same as in reinstatement. ${ }^{216}$ The tribunal is obliged to make the terms of re-engagement "so far as is reasonably practicable as favourable as an order of reinstatement", except that contributory "blameworthiness" may be taken into account to reduce benefits.

In arbitration, it is almost certain that the labour relations statutes confer jurisdiction to order reinstatement even though the collective agreement is silent on the matter.217 No arbitration award has been challenged on this ground. It would impair the purpose of arbitration, and

210. See the Report of Standing Committee F. on the E.P. Bill, 2 lst sitting, July 3, 1975, cols. 109-1100.

211. E.P.A. 8. 72(5).

212. E.P.A. s. $71(1)$ and (6).

213. E.P.A. 8. $71(8)$.

214. E.P.A. s. 71(4) and (9).

215. E.P.A. s. $71(5)$.

216. E.P.A. s. $71(7)$, (8) and (9).

217. See A.G. v. Newfoundland Assoc. of Public Employees, May 11, 1977 (S.C.C.). The British Columbia Labour Code s. $98(b)$ is unique in expressly conferring this power on arbitrators. 
therefore of labour legislation itself, were it otherwise. Further, in most provinces the labour relations legislation empowers arbitrators to substitute a lesser penalty (for example, an unpaid suspension) and reinstate the grievor where his partial "fault" does not warrant reinstatement with full back-pay; however, this is only if the agreement does not specify a particular penalty for the offence. ${ }^{218}$

In Nova Scotia, the Tribunal's jurisdiction under s. 24(2) of the Code is broad enough to encompass orders of reinstatement and re-engagement and the terms thereof. However, the poor field record of reinstatement (of eight successful claims between March 1975 and July 1976 only one employee was reinstated), parallels the early English experience. It is suggested that the Labour Standards Code be amended to emphasize the primary remedy of reinstatement. Clause 61.5(9) of the federal Code empowers the adjudicator, upon finding dismissal to be "unjust", to order reinstatement and compensation. The present wording of the clause can be construed to require the order to be for compensation and reinstatement, not compensation and/or reinstatement. This is surely unintended, for it would mean that an unfairly dismissed employee who does not want his job back, or where reinstatement is otherwise not practicable, would not be entitled to compensation. The clause should be re-drafted to make its construction clear.

In England, enforcement of the reinstatement/re-engagement orders is exclusively by way of an "additional award" compensating the worker for the employer's failure to comply, ${ }^{219}$ unlike in grievance arbitration where awards are filed as orders of the court and ultimately enforced through contempt proceedings. Employers may therefore be willing to pay in order to rid themselves of "troublemakers". In Nova Scotia, non-compliance with non-monetary orders of the Tribunal results in prosecution. ${ }^{220}$ This may involve delay and undue legal technicalities. Clauses 61.5(12) and (13) of the Federal Code follow the arbitration approach which, it is submitted, is preferable.

\section{Monetary Compensation}

In England, the legislation is highly sophisticated in its treatment of compensation. The maximum possible sum recoverable is $£ 11,760.221$ Compensation can only be awarded as a "last resort" if reinstatement and re-engagement are not ordered. Under the pre-1975 law, over $60 \%$ of awards totalled less than $£ 300$ so that employers could often rid themselves of "undesirables" fairly cheaply.222 Accordingly, the philosophy of the 1975 amendments ceased to be compensatory and, in principle at least, sought to provide workers with a "floor of rights" monetary "cushion" not based on their actual losses. This "basic award" is too low both for "cushioning" the employee and for deterring unfair dismissals. In addition to the "basic award" the employee is entitled to a "compensatory award" supposedly representing his actual losses.

\section{(a) The "Basic Award"}

This is calculated the same as redundancy payments. First, the number of years of "continuous employment" are counted back from the

218. For example, see the Alberta Labour Act s. 138(4)(g).

219. Labour Standards Code s. 90 . In the case of money orders, the process culminates in a civil action, $s .86$.

220. E.P.A. 8. 72 .

221. Calculated in Hepple and O'Higgins, supra, n. 50 at para. 1-399-3.

222. Report of Standicng Committee F on the F.P. Bill, 22nd Sitting. July 22, 1975, col. 1137. 
"effective date of termination" up to an arbitrary ceiling of 20 years. ${ }^{223}$ Secondly, on the basis of the worker's weekly pay (subject to an arbitrary ceiling of $£ 80$ per week) the following calculation is made:

$-1 \frac{1}{2}$ weeks' pay for each year of service when the worker was below the age of 41

-1 week's pay for each year between the ages of 41 and 22

$-1 / 2$ week's pay for each year between 18 and 21 .

Then the following deductions are made from the total: first, in respect of the worker's contributory "blameworthiness" for the dismissal, save in redundancy discharges, and secondly, statutory or private redundancy payments received pursuant to the unfair dismissal. If the amount of the redundancy payment exceeds the "basic award", the excess is deducted from the compensatory award. However, the duty to mitigate does not apply in respect of the "basic award". Further, the amount of the award decreases in the year preceding retirement and is extinguished upon retirement. Otherwise, section $74(2)$ provides that the irreducible "basic award" should be two weeks' pay.

\section{(b) The "Compensatory Award"224}

This represents "such amount as the tribunal considers just and equitable in all the circumstances having regard to the loss sustained by the complainant in consequence of the dismissal so far as that loss is attributable to action taken by the employer."225 The maximum sum recoverable is $£ 5,200$.

The courts have held that the common law principles are irrelevant in assessing compensation, ${ }^{226}$ but the duty to mitigate still applies, ${ }^{227}$ and unemployment benefits and tax are deducted from wages before they are received by the worker. ${ }^{228}$ In other respects, the rules are more realistic than at common law.

First, compensation is recoverable for economic loss flowing from the manner of dismissal. ${ }^{229}$ It is not recoverable for mental suffering, injury to reputation itself, or loss of "job satisfaction", although it is difficult to see why not. Paradoxically, the common law compensates the latter but not the former! 230

Secondly, loss of future benefits is not restricted to the period of notice to terminate. As regards wages, if the employee has taken a second job at less pay than the previous one, the tribunal projects the period of time during which the worker can be expected to remain at the lesser wage before catching up. If the worker has not obtained other work, it projects his likely period of unemployment having regard to the local labour market, the worker's age and market attractiveness and the wage differences between the old and future jobs. However, the length of time over which this projection can be made may be "cut off" by supervening events (for example, it it is almost certain that the worker will be made

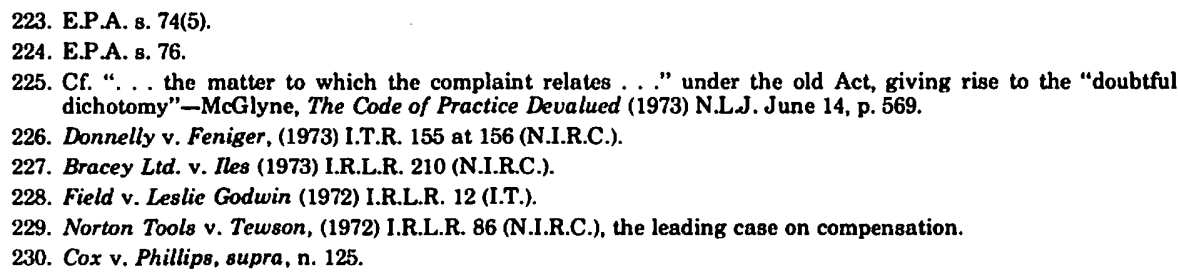


redundant), in which case loss of wages will only run up to the event. ${ }^{231}$ In addition, extra compensation can be given if the future job is likely to be less secure than the old one. In making such projections, the tribunals ". . . are entitled to draw on their knowledge of the local employment situation."'232 Further, unlike at common law, the worker is compensated for non-contractually binding wage increases and bonuses that he would reasonably be expected to have earned, provided that these are capable of quantification. ${ }^{233}$

Fringe benefits are compensable on the same principle as wages. As regards pensions, the employee can recover his own and his employer's past contributions, and his employer's future contributions up to the time he either does or can be expected to find another job, ${ }^{234}$ having regard to the actuality or likelihood of his receiving equivalent pension benefits in the future job. Also, the tribunal may reduce the amount according to the possibility that the worker would have left the job before maturity or that other factors would have prevented maturity.

Loss of statutory "seniority" for the purposes of protection against unfair dismissal and redundancy benefits has always been compensated. The former is likely to be nominal since the reduction of the qualifying period to 26 weeks' "continuous employment". The latter is now governed by section 76(3) of the Employment Protection Act which provides that loss of vested or expected redundancy benefits, whether statutory or private, are not compensated except insofar as the amount would have exceeded the "basic award" before deductions are made therefrom. The policy is not to double-compensate the worker in respect to redundancy benefits. Moreover, where the employer has actually made a redundancy payment in excess of the basic award, section $76(3)$ requires that the excess amount be deducted from the "compensatory award".

\section{Reduction of Compensation for Contributory "Blameworthiness" on the Part of the Employee}

Section 76(6) of the Employment Protection Act requires tribunals to reduce the "compensatory award" (but not the "basic award") by an amount it considers "just and equitable" where the tribunal finds "that the dismissal was to any extent caused or contributed to by any action of the complainant".235 Tribunals have generally been unwilling to reduce compensation to a nil amount because the dismissal is still technically "unfair" and a nil award would devalue the procedural safeguards."236 Thus, in Kemp v. Shipton Automatic Ltd.,237 Phillips J. said the maximum reduction should be $80 \%$. However, in Devis Ltd. v. Atkins, the House of Lords suggested obiter that a nil award is acceptable lest, "the compensation provisions for unfair dismissal would have been converted into a vertiable rogue's charter". ${ }^{238}$ Further, their Lordships recommended that the Act be amended to permit the reduction of the "basic award" to a nil amount. It is submitted that nil awards should never be made.

\footnotetext{
231. Herbert v. G.E.C. Power Engineering 9965/72 (I.T.).

232. Donnelly v. Feniger, supra, n. 226 at 27.

233. York Trailer v. Sparkes (1973) I.C.R. 518 (N.I.R.C.).

234. Gill v. Andrews (1974) I.R.C. 294 (N.I.R.C.). See especially Jackson, Compensation for Loss of Pension Rights in Cases of Unfair Dismissal (1975) 4 I.L.J. 24.

235. The old position is criticized by McGlyne, supra, n. 225 .

236. Cf. Maris v. Rotherham County Borough Council (1974) I.R.L.R. 147 (N.I.R.C.).

237. (1976) I.R.L.R. 305 (E.A.T.)

238. Per Diplock L.J., supra, n. 179 at 316.
} 
Whereas the stigma of "unfair" dismissal may have some deterrent impact on employers, they should also have to pay some compensation in order to uphold the integrity of procedures. Indeed, the Act states that an award of compensation "shall" 239 be made. If that is a windfall to the employee, albeit a small one, then so be it!

In contrast, the Nova Scotia Code does not provide guidelines as to method of assessing compensation for unjust discharge. Of the successful claims between March 1975 and July 1977, 5 employees received compensation totalling $\$ 18,781.25$ (the highest award being $\$ 9,200.00$, the lowest, $\$ 973.80$ ). Section 24(2)(b) states that the Tribunal "may" award compensation for the "injury" sustained by the complainant. This is broad enough to allow the Tribunal to avoid the restrictions imposed by the common law, although "shall" should replace "may". Thus, the Code allows the Tribunal to award compensation for the manner of discharge and economic loss flowing therefrom. It also allows the Tribunal to compensate loss of protection against "unjust discharge", which is likely to be high in view of the ten year qualifying period, and to make deductions for contributory "blameworthiness". Since Nova Scotia does not have a statutory redundancy payments scheme, compensation would presumably not be awarded for loss of accrued redundancy benefits, unless the employer operates a private redundancy scheme. It is doubtful whether loss of the job per se would be compensated without a clear legislative mandate.

Clause 61.5(9)(a) of the federal Code empowers the adjudicator to order compensation "not exceeding the amount of money that is equivalent to the remuneration that would, but for the dismissal, have been paid by the employer..."This can be construed as permitting deductions for contributory "blameworthiness", whether the employee is reinstated or not. The clause does not seem to contemplate compensation for items not constituting "remuneration" (undefined), for example, injury to reputation, loss of protection against unjust dismissal, and arguably, private redundancy schemes. The words "but for the dismissal" may be construed narrowly so as to restrict damages to the contractual notice period, as at common law, but hopefully the clause will not be applied in this way. The clause should be redrafted to clarify its construction, and to include "nonwage" heads of loss.

\section{CONCLUSION}

It has been suggested, that in the interests of the worker, the employer and society as a whole, the seriousness of dismissal necessitates certain minimum "fairness" safeguards being imposed on the employer's power to dismiss. The common law does not provide for these safeguards, although the trend in recent cases is to move in this direction. Therefore, statutory "unfair dismissal" protection is urgently needed; the Nova Scotia legislation and the proposed amendments to the Canada Labour Code are a welcome, though somewhat crude, step in this direction. The experience in Nova Scotia, the English legislation, the federal Code and grievance arbitration is highly relevant in formulating such a statute. To varying degrees those systems contain most, but not all, of the minimum "fairness" standards suggested in this paper. 